\title{
Participant responses to physical, open-ended interactive digital artworks: a systematic review
}

\section{Tom Luyten*}

Research Centre for Technology in Care,

Henri Dunantstraat 2, 6419 PB,

Heerlen, The Netherlands

Email: tom.luyten@zuyd.nl

*Corresponding author

\section{Susy Braun}

Research Centre Autonomy and Participation,

Nieuw Eyckholt 300,

6419 DJ Heerlen, The Netherlands

Email: susy.braun@zuyd.nl

\section{Susan van Hooren}

Research Centre for Arts Therapies,

Nieuw Eyckholt 300,

6419 DJ Heerlen, The Netherlands

Email: susan.vanhooren@zuyd.nl

\section{Luc de Witte}

Health Services Research,

CAPHRI School for Public Health and Primary Care,

Universiteitssingel 40,

6229 ER Maastricht, The Netherlands

Email: l.dewitte@maastrichtuniversity.nl

\begin{abstract}
The main aim of this systematic review was to describe responses of participants to physical, open-ended interactive digital artworks. Although human-to-artwork and human-to-human responses were found in the 22 identified artworks, more human-to-artwork responses were reported. Both types of responses were further categorised into physical, verbal, and cognitive/emotional responses. The artworks varied from small table-top installations to large, dark open spaces, and had a range of interactive components and features from a heart rate interface to complete body movements. Results imply there is no straightforward relationship between the features of the artwork and the kind of response. However, two factors seemed to influence the participants' responses: the content (concrete or abstract) of the artwork, and the presence of others. Creating interactive artworks that challenge new audiences and/or evoke specific responses requires more knowledge about the dynamics of the interaction between people and interactive artworks.
\end{abstract}


Keywords: participant; user; responses; interaction; interactive; open-ended; art; interactive art; artwork; installation; systematic review; literature.

Reference to this paper should be made as follows: Luyten, T., Braun, S., van Hooren, S. and de Witte, L. (2017) 'Participant responses to physical, open-ended interactive digital artworks: a systematic review', Int. J. Arts and Technology, Vol. 10, No. 2, pp.94-134.

Biographical notes: Tom Luyten is a Digital Artist and Teacher at the Maastricht Academy of Media, Design and Technology and a Researcher at the Research Centre for Technology in Care at Zuyd University of Applied Sciences in Heerlen and CAPHRI School for Public Health and Primary Care at Maastricht University. He is interested in the potential of interactive art as care technology.

Susy Braun is a Teacher/Researcher at the Research Centre for Autonomy and Participation at Zuyd University of Applied Sciences in Heerlen and CAPHRI School for Public Health and Primary Care at Maastricht University. She is especially interested in motor learning and physical practice within rehabilitation, motor learning of every day movements, skill acquisition and exercise and the potential role of technology to create challenging motor learning environments (like exergaming or virtual realities) within motor learning.

Susan van Hooren is an Associate Professor at Zuyd University of Applied Sciences and Open University of The Netherlands. She is the Head of the Research Centre of Arts Therapies in The Netherlands, known as KenVaK and is Head of the Masters of Arts Therapies. During her career, she combined practice-based research with teaching activities and clinical work. Her research, supervising, and teaching focus on evaluating (arts) therapeutic interventions, aging, sexology, e-mental health, and clinical psychology, resulting in many publications in high ranking peer reviewed journals and contributions on national and international conferences.

Luc de Witte is a Professor specialised in Technology in Care and the Director of the Centre of Expertise for Innovative Care and Technology (EIZT), which is a collaboration of about 35 partners in healthcare and industry, jointly working on a common research and innovation program around the development and implementation of technology to support long term care. Since 1991, he has been involved in over 200 publications in peer reviewed journals. He worked on different research areas, but all relating to long-term care and the last seven to eight years relating to the use of technology in longterm care. Since October 2016, he is a Professor of Health Services Research at the University of Sheffield in the UK.

\section{Introduction}

Enjoying art is a uniquely human capacity. A piece of art has the power to evoke thoughts and emotions (Robinson, 2007). Listening to your favourite song can make your day, while a modern art sculpture can provoke thoughts on ethics or the lightness of being. In non-interactive art, the artist is the creator. He/she shapes his/her ideas until he/she is satisfied, and then shares them with the world. The spectator, in turn, looks at the work and interprets it. If the piece is modified by this user interaction, it becomes interactive art (Nardelli, 2012). 
With the advent of interactive artworks, the division between artist and audience has started to fade. In the words of Edmonds and Candy (2011): "in the past, we might have said that 'making' art is the prerogative of the artist whilst viewing it [is] that of the audience. In many ways, the phenomenon of 'interactive art' has transformed longstanding notions of what it is to be a creator and a consumer".

Interactive works of art thrive on being touched and experimented with; the passive viewer becomes an active participant and plays an important role in the final outcome of the work. In interactive art, the participant can touch, try out, and engage, which lowers the threshold to participating in the artworks and makes them more accessible. The participant becomes part of the artwork, and the meaning is formed during and through the interaction with the object ['embodied interaction' (Dourish, 2004)].

Figure 1 PRISMA 2009 flow diagram (see online version for colours)

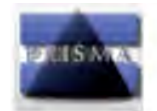

PRISMA 2009 Flow Diagram
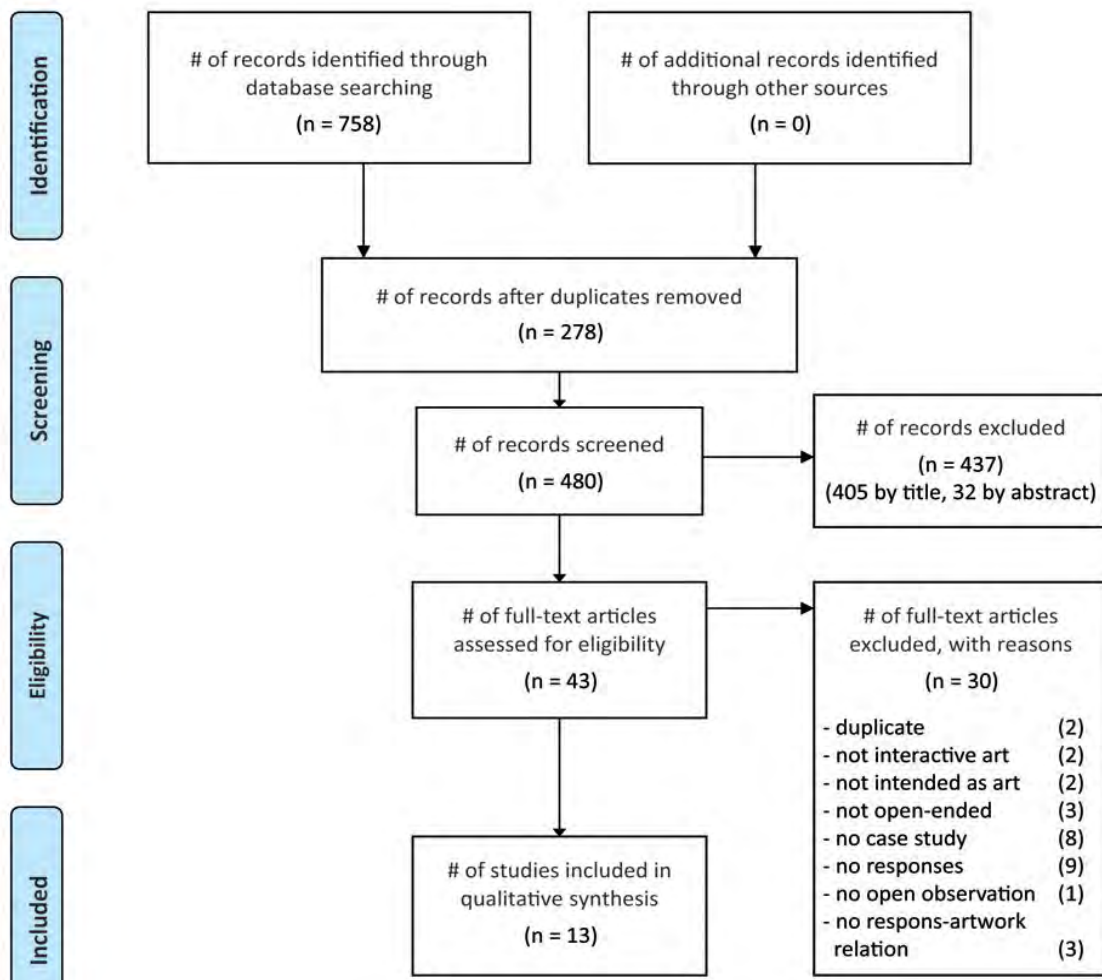

Source: Moher et al. (2009) and for more information, visit http://www.prisma-statement.org

Interactive art comes in many shapes and forms. Figure 2 shows nine artworks in a matrix that ranges from virtual and scripted works like the art video game swords and sworcery (Capybara Games and Superbrothers, 2011) [Figure 2(g)] to completely open-ended and 
physical works like the grid of plastic bags that reacts to movement in one hundred and eight (Völker, 2010) [Figure 2(c)].

Figure 2 Nine interactive artworks in a two-axis matrix (see online version for colours)

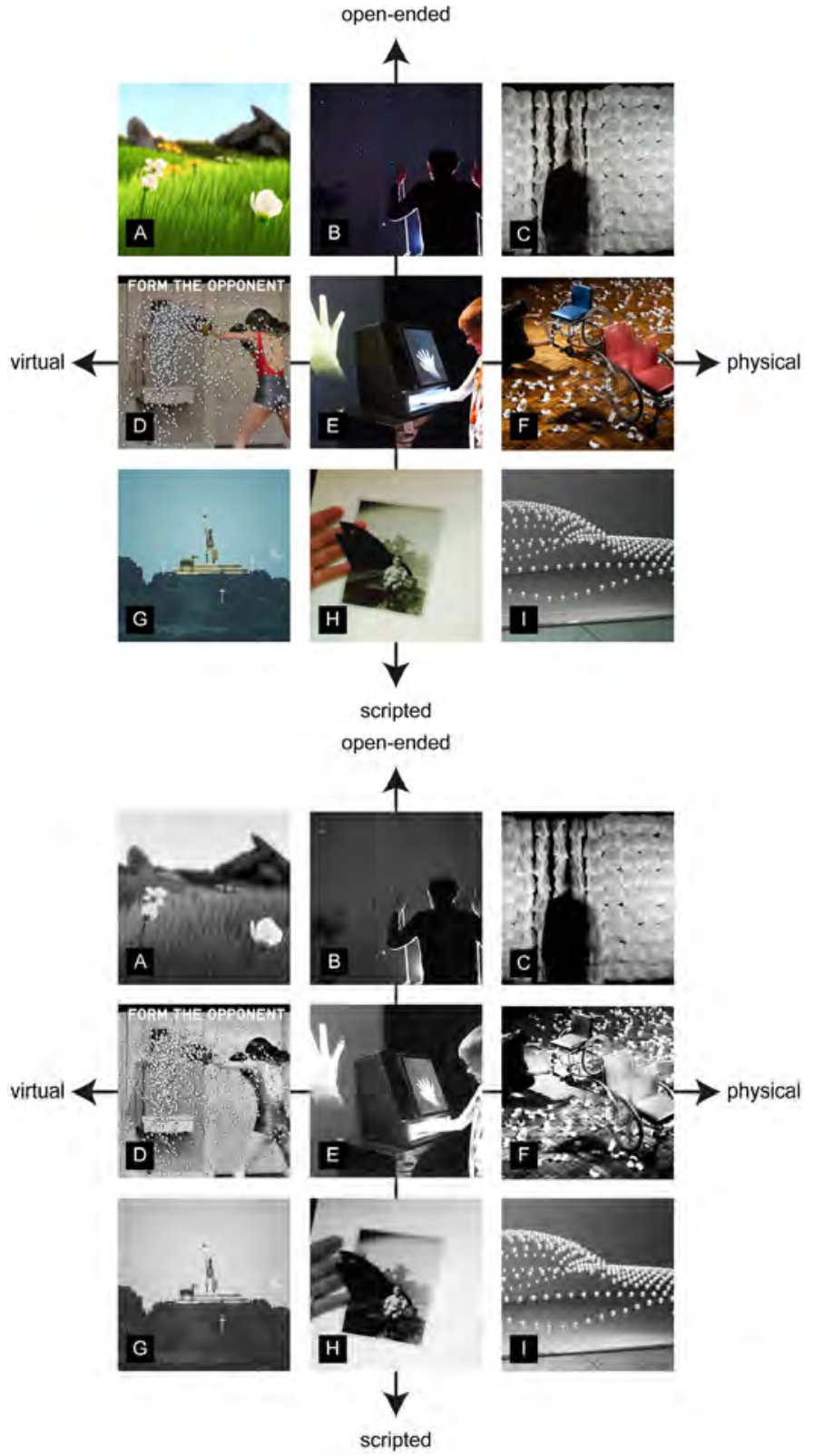

Notes: Open-ended to scripted and virtual to physical; (a) flower - Thatgamecompany and SuperVillain Studios, (b) starfield - Lab212 (c) one hundred and eight - Nils Völker, (d) do not touch - Moniker, (e) augmented hand series - Golan Levin, Chris Sugrue and Kyle McDonald, (f) fish and bird - Mari Velonaki, (g) sword \& sworcery - Capybara Games and Superbrothers, (h) Le monde des montagnes Camille Scherrer, (i) kinetic sculpture BMW - ART+COM studios. 
Although all examples of interactive artwork cited above are driven by electronics or computer technology, this is not a requirement. For instance, drawing machine \#1 by Griffiths (2009) (Figure 3) is a stationary bicycle that draws varying patterns using felt-tip markers and purely mechanical transfers.

Figure 3 Drawing machine \#1 by Joseph L. Griffiths (see online version for colours)

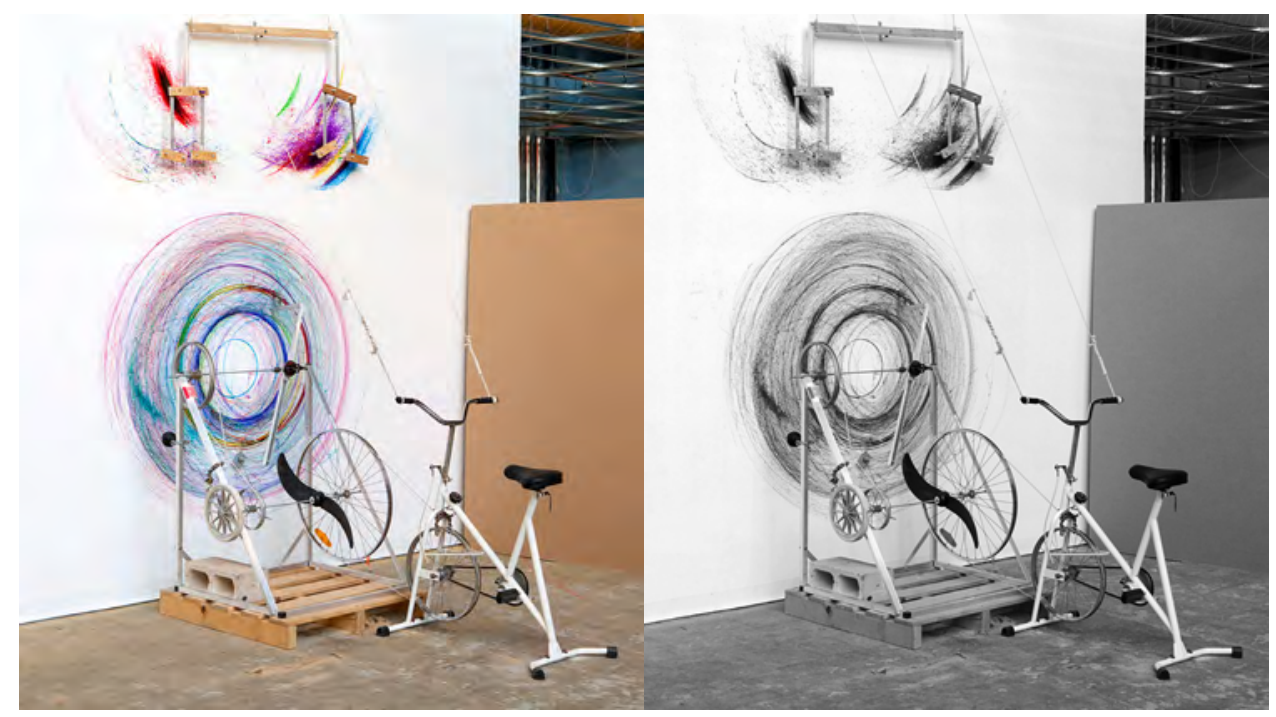

Note: A purely mechanical interactive artwork.

Source: Griffiths (2009)

Because of their fun nature and the attractiveness of participating in/interacting with them, interactive (art) installations are not only used to create aesthetic experiences in museums but are also now appearing in various other places to evoke specific responses between the participant and the artwork (human-to-artwork interaction) or responses between participants (human-to-human interactions). As Her and Hamlyn (2010) noted: "Some of [these works] have even been placed as permanent installations with specific artistic intentions that relate to various public contexts". Examples of intentional interactive installations are branch out (Burke et al., 2012) [Figure 4(a)], which triggers dialogue between strangers, BrightHearts (SensoriumHealth, 2014) [Figure 4(b)] which relieves pain and enhances relaxation, and moodwall (Klink and Urban Alliance, 2009) [Figure 4(c)] which tries to change one's perception of a neighbourhood.

Despite the creation of an increasing number of interactive installations, research on user experiences with them is scarce. In 2012, Schraffenberger and van der Heide (2012) published a literature review presenting the known interaction models for audience-artwork interaction. They identified frameworks that discuss artwork characteristics, user interactions with them, or both. Similarly, Jacucci et al. (2009) listed frameworks for studying aesthetic experiences with interactive art. However, none of these studies or the frameworks identified in them report actual participant responses. 
Figure 4 Three intentional interactive installations, (a) branch out (b) BrightHearts (c) moodwall (see online version for colours)
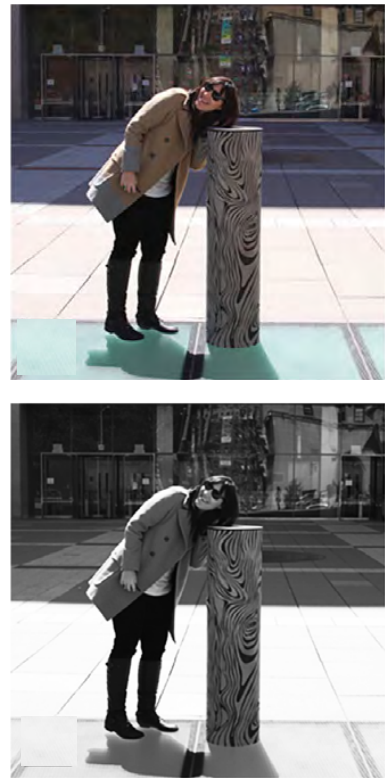

(a)
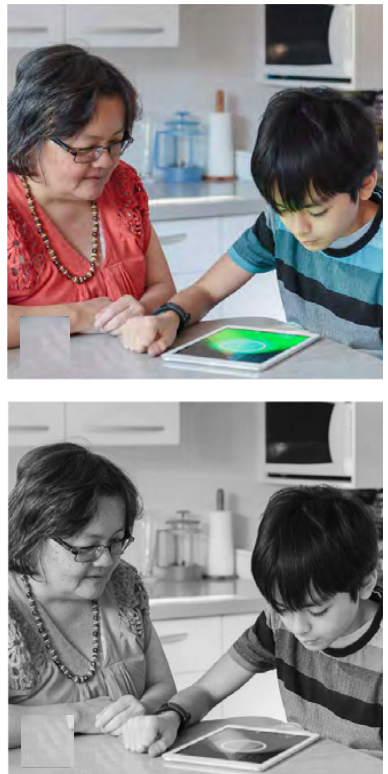

(b)
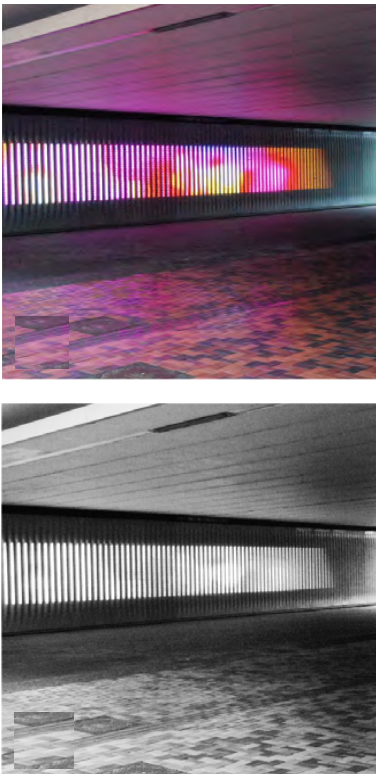

(c)

Source: (a) Burke et al. (2012) (b) SensoriumHealth (2014) and (c) Klink and Urban Alliance (2009)

Figure 5 Four physical open-ended interactive digital artworks, (a) lunar (b) Starfield (c) Water Light Graffiti (d) Weather Worlds (see online version for colours)
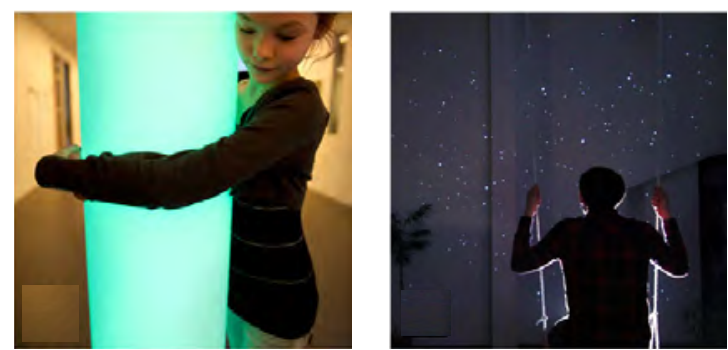

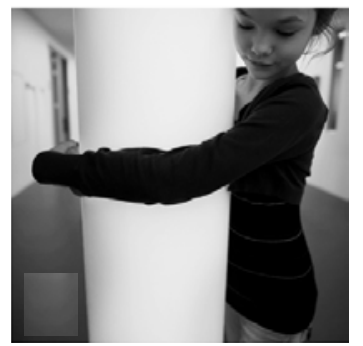

(a)

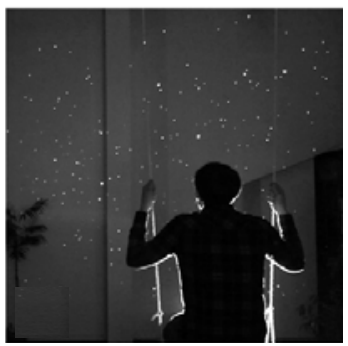

(b)

Source: (a) Roosegaarde (2011), Lab212 (2012), Fourneau (2013) and I/O (2013) 
Figure 5 Four physical open-ended interactive digital artworks, (a) lunar (b) Starfield (c) Water Light Graffiti (d) Weather Worlds (continued) (see online version for colours)
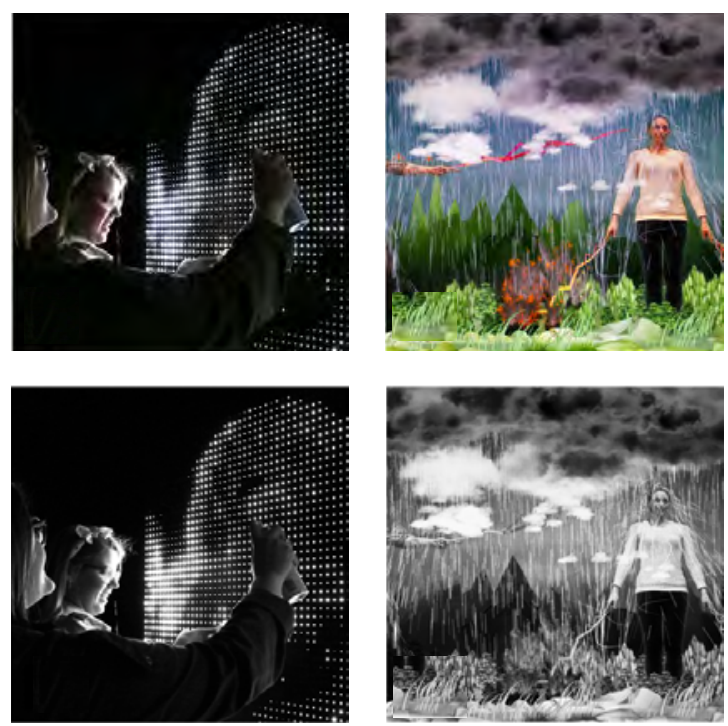

(c)

(d)

Source: (a) Roosegaarde (2011), Lab212 (2012), Fourneau (2013) and I/O (2013)

The present review focuses on physical, open-ended interactive digital artworks, because of their potential as intentional works of art. The term 'physical' here excludes works that exist only in virtual space, such as video games, website art, or mobile phone applications. The term 'open-ended' implies that the artwork has no scripted narrative, and that participants are able to enter or leave the interaction at any moment. The interaction, that is, has no defined beginning or end. The term 'interactive' excludes works where the output is not influenced by the actions of the participant. Finally, 'digital' is defined here as involving reliance on electronics and/or computation, meaning that it excludes works that are purely mechanical. Examples of physical open-ended interactive digital artworks include lunar by Roosegaarde (2011) [Figure 5(a)], Starfield by Lab212 (2012) [Figure 5(b)], Water Light Graffiti by Fourneau (2013) [Figure 5(c)], and Weather Worlds by Design I/O (I/O, 2013) [Figure 5(d)].

\section{Objective}

The objective of this paper is to present an overview of participant responses, both human-to-artwork and human-to-human, in relation to physical, open-ended interactive digital artworks. 


\section{Methods}

\subsection{Search strategy}

A computer-supported search was conducted by the first author (TL) in the following databases:

- $\quad$ Taylor and Francis Online (http://www.tandfonline.com)

- $\quad$ ACM Digital Library (http://dl.acm.org)

- $\quad$ IEEE Xplore (http://www.ieee.org)

- $\quad$ Springer Link (http://link.springer.com)

- Google Scholar (http://scholar.google.com).

In view of the large number of terms used to identify these interactive artworks by their authors, a search strategy was defined that combined multiple terms (Figure 6). Not all databases used for this search could handle the initial query, so an alternative search was performed with a shorter query.

Figure 6 Search query design

\section{A. Query design:}

\begin{tabular}{|c|c|c|c|c|c|c|}
\hline Interactive & \multirow{6}{*}{ AND } & Art & \multirow{9}{*}{ AND } & Audience & \multirow{6}{*}{ AND } & Interaction \\
\hline \multirow[t]{5}{*}{ Open-ended } & & Artwork* & & Participant" & & Reaction \\
\hline & & Environment" & & Participator" & & Experience \\
\hline & & Installation* & & User* & & Participation \\
\hline & & $\begin{array}{l}\text { Art } \\
\text { installation* }\end{array}$ & & Human-computer & & Behaviour \\
\hline & & $\begin{array}{l}\text { Art } \\
\text { enviranment* }\end{array}$ & & Human-robot & & Play \\
\hline & & & & OR & & \\
\hline & & & & $\mathrm{HCl}$ & & \\
\hline & & & & UX & & \\
\hline
\end{tabular}

B. Query 1:

((interactive OR "open end") AND (art OR artwork* OR installation" OR "art installation"" OR "art environment ${ }^{* \prime \prime}$ OR environment"))

AND

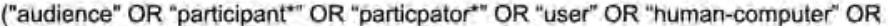

"human robot" AND (interaction OR reaction OR experience OR participation OR behaviour OR play) OR $\mathrm{HCl}$ OR UX)

C. Query 2:

(behaviour OR behavior OR interaction OR play OR results) AND ("interactive artwork" OR "interactive installation") 


\subsection{Study selection}

All eligible journal articles, conference proceedings, book sections, and doctoral theses published in English between January 2008 and April 2014 and providing a qualitative or quantitative description of participant responses regarding physical open-ended interactive digital artworks were eligible for inclusion in this review. The studies to be included were selected independently by three of the researchers (TL, TD, SB). An overview of the selection process can be found in Figure 1. Selection took place based firstly on title, secondly on abstract, and thirdly on full text. Each researcher assigned to each study a score ranging from 0 to 2: a score of 0 recommended that the article be excluded, a score of 1 meant doubt, and a score of 2 meant it should be included. The scores of the three researchers were added up, and articles with a total score of 3 and higher were included.

\subsection{Data extraction}

Data regarding the number of times and the period during which a work is/was exhibited, the physical appearance of the artwork, interaction options (input and output), the number of participants (number of people observing), and the recorded user responses were extracted. The quality of the studies was not assessed. The extracted user response data was split into human-to-artwork responses and human-to-human responses, and divided further into verbal, physical, and cognitive/emotional responses. Verbal responses were defined as comprehensible audible feedback and physical responses as any observable bodily movement. Feelings and experiences observed in or reported by participants in response to or as a result of questions were categorised as cognitive/emotional responses.

An overview of the interactive artworks, with a description of their appearance and workings (interaction possibilities), can be found in Table 3. The extracted participant responses are listed in Tables 4 and 5. If user responses to an artwork were evaluated over multiple sessions, the results were combined in this review for ease of reference.

\section{Results}

\subsection{Selection process}

An overview of the selection process is shown in Figure 1. The search strategy resulted in 758 potentially relevant articles, 278 of which were duplicates due to the use of two queries. The title screening involved 480 titles which were screened and scored by three reviewers (TL, SB, TD), resulting in 405 being excluded. The other 75 titles each had a total score of 3 or more, meaning they proceeded to abstract screening. In the abstract screening stage, 43 of the articles attained a total score of 3 or more and were therefore forwarded to full-text review. During this final selection round, consensus (i.e., a total score of 6 , or 2 from each researcher) was needed for the articles to be included in data extraction. Ultimately, 13 articles were included (Bialoskorski et al., 2010; Costello et al., 2005; Deray and Simoff, 2012; Gurion and Jacoby, 2013; Her and Hamlyn, 2010; Hespanhol and Tomitsch, 2014; Hohl, 2009; Jacucci et al., 2009; Morgan and Gunes, 2013; Morrison et al., 2011b, 2008, 2011a; Muller, 2008). 


\subsection{Data extraction}

In all, 13 articles were included in the analysis (Table 1), discussing 22 artworks (Table 1; Figure 7).

Table 1 Overview of articles extracted and artworks studied in them

\begin{tabular}{|c|c|c|}
\hline \multicolumn{2}{|l|}{ Study } & \multirow{2}{*}{ Artworks studied } \\
\hline First author & Title & \\
\hline Gurion, T. & $\begin{array}{l}\text { Audio-only augmented reality for } \\
\text { social interaction }\end{array}$ & $\begin{array}{l}\text { Audio-only augmented reality system } \\
\text { for social interaction [Figure 7(a)] }\end{array}$ \\
\hline Jacucci, G. & $\begin{array}{l}\text { Bodily explorations in space: social } \\
\text { experience of a multimodal art } \\
\text { installation }\end{array}$ & $\begin{array}{c}\text { Galassie [Figure 7(b)] } \\
\text { Ombra di Stelle [Figure 7(c)] }\end{array}$ \\
\hline Morrison, A. & $\begin{array}{l}\text { Building sensitising terms to } \\
\text { understand free-play in open-ended } \\
\text { interactive art environments }\end{array}$ & $\begin{array}{c}\text { ALAV [Figure 7(d)] } \\
\text { Drafting poems [Figure 7(e)] } \\
\text { Books of sand [Figure } 7(\mathrm{f})]\end{array}$ \\
\hline Hohl, M. & $\begin{array}{l}\text { Designing the art experience: using } \\
\text { grounded theory to develop a model of } \\
\text { participants' perception of an } \\
\text { immersive telematic artwork }\end{array}$ & Radiomap [Figure 7(g)] \\
\hline Morrison, A. & Evoking gestures in interactive art & Space of two categories [Figure 7(h)] \\
\hline Bialoskorski, L. & Experiencing affective interactive art & Mood swings [Figure 7(i)] \\
\hline Deray, K. & $\begin{array}{l}\text { Framing interaction through } \\
\text { engagement in interactive open ended } \\
\text { environments }\end{array}$ & High arctic [Figure 7(j)] \\
\hline Her, J. & $\begin{array}{l}\text { Meaningful engagement: computer- } \\
\text { based interactive media art in public } \\
\text { space }\end{array}$ & $\begin{array}{l}\text { Event horizon [Fig. 7(k)] } \\
\text { Untitled [Figure 7(l)] }\end{array}$ \\
\hline Morrison, A. & $\begin{array}{l}\text { Open-ended art environments motivate } \\
\text { participation }\end{array}$ & Talk2me [Figure 7(m)] \\
\hline \multirow[t]{3}{*}{ Costello, B. } & \multirow{3}{*}{$\begin{array}{l}\text { Understanding the experience of } \\
\text { interactive art: iamascope in } \\
\text { beta_space }\end{array}$} & $\begin{array}{l}\text { Elysian Fields [Figure 7(n)] } \\
\text { Sprung! [Figure 7(o)] }\end{array}$ \\
\hline & & $\begin{array}{c}\text { Just a bit of spin (prototype) [Figure } \\
7(\mathrm{p})]\end{array}$ \\
\hline & & $\begin{array}{c}\text { Just a bit of spin (redesign) [Figure } \\
7(\mathrm{p})]\end{array}$ \\
\hline Hespanhol, H. & $\begin{array}{l}\text { Understanding the effects of } \\
\text { contextual constraints on performative } \\
\text { behaviour in interactive media } \\
\text { installations }\end{array}$ & Metastasis [Figure 7(q)] \\
\hline Morgan, E. & $\begin{array}{l}\text { Human non-verbal behaviour } \\
\text { understanding in the wild for new } \\
\text { media art }\end{array}$ & The mood conductor [Figure 7(r)] \\
\hline \multirow[t]{3}{*}{ Muller, E. } & $\begin{array}{l}\text { The experience of interactive art: a } \\
\text { curatorial study }\end{array}$ & $\begin{array}{l}\text { Cardiomorphologies (prototype) } \\
\text { [Figure } 7(\mathrm{~s})]\end{array}$ \\
\hline & & Contagion (prototype) [Figure 7(t)] \\
\hline & & Contagion (finished) [Figure 7(t)] \\
\hline
\end{tabular}


Table 2 Overview of study characteristics

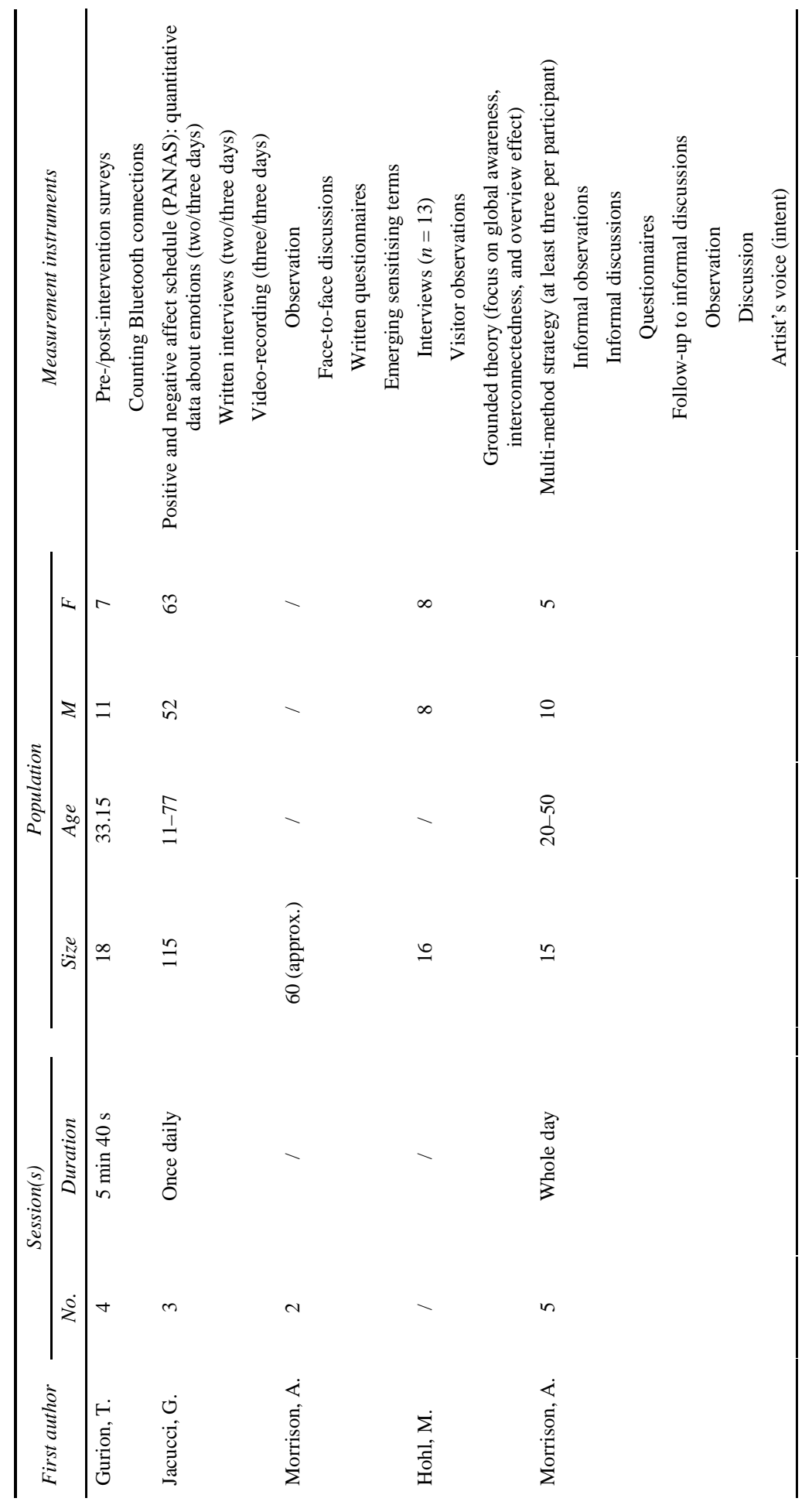


Table 2 Overview of study characteristics (continued)

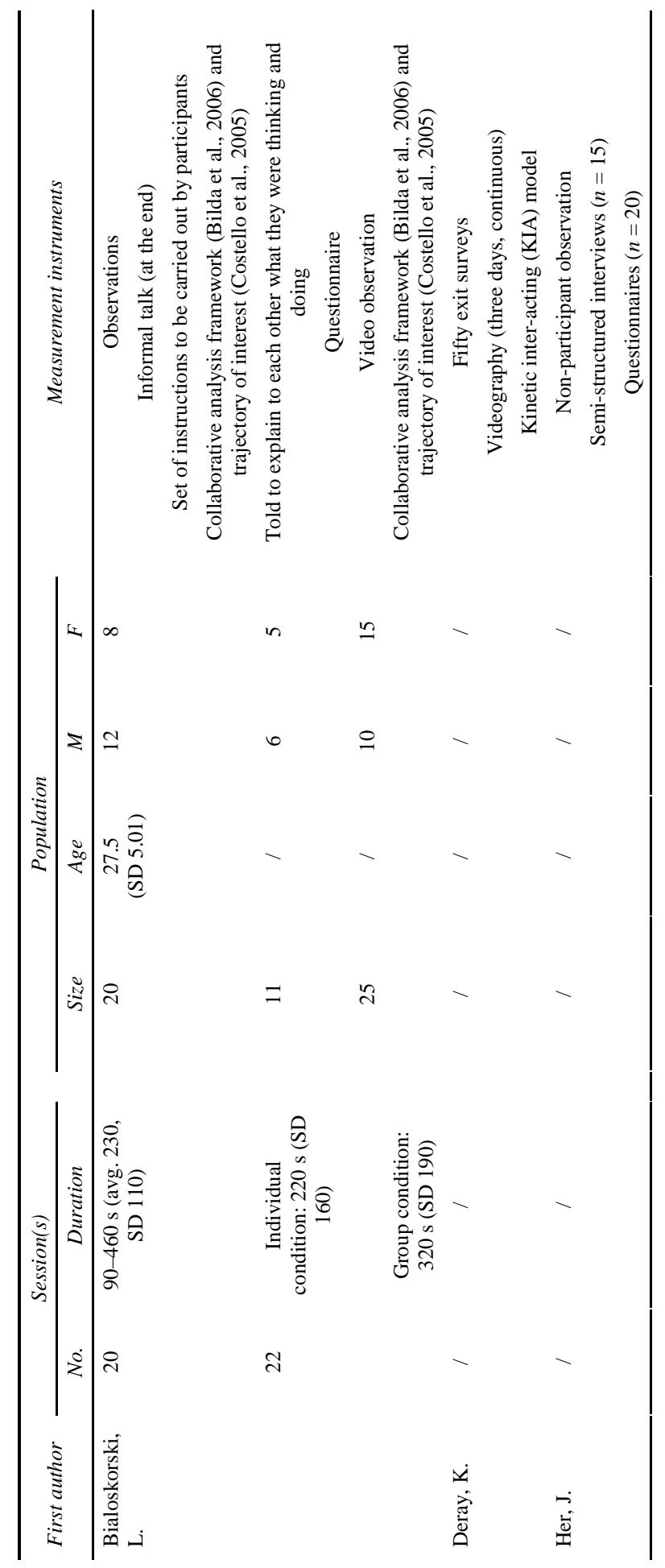


Table 2 Overview of study characteristics (continued)

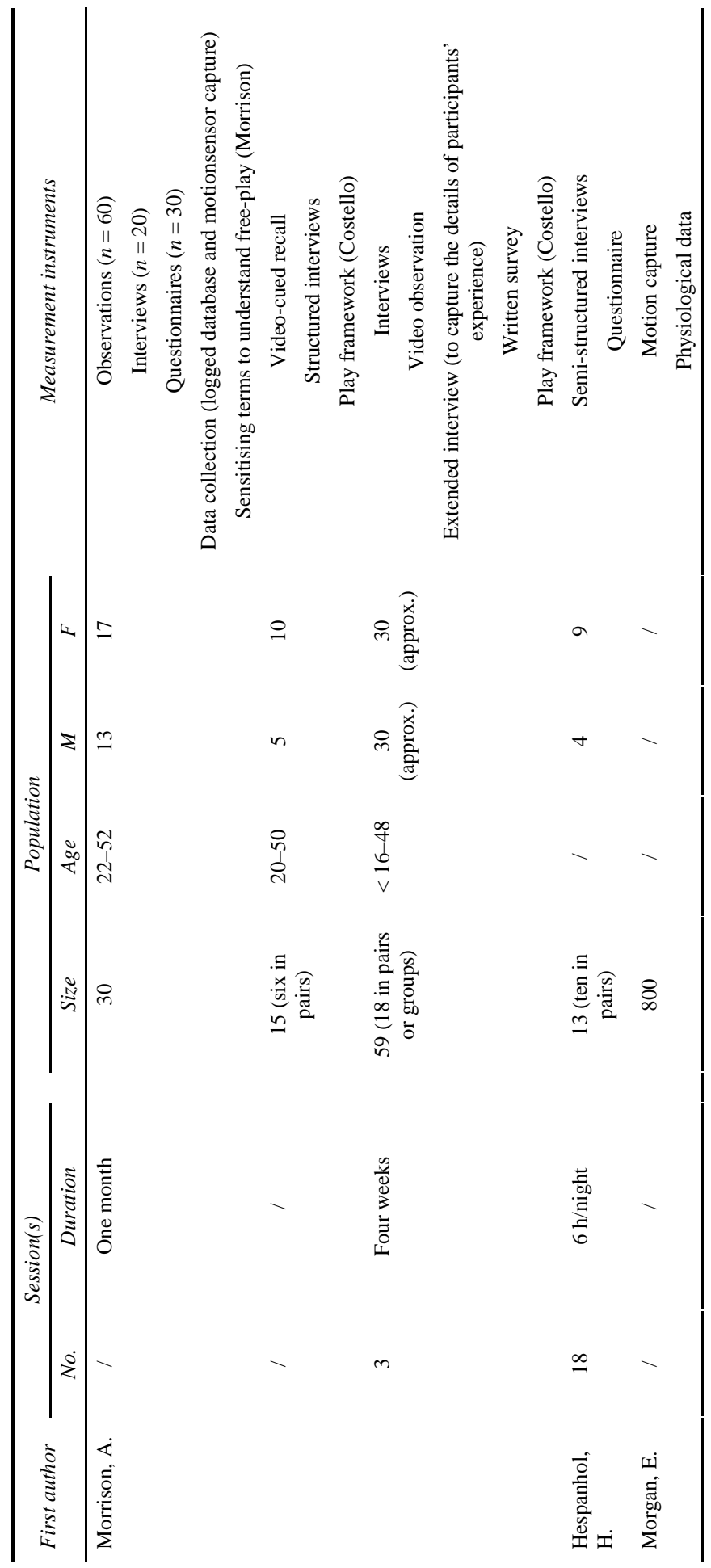


Table 2 Overview of study characteristics (continued)

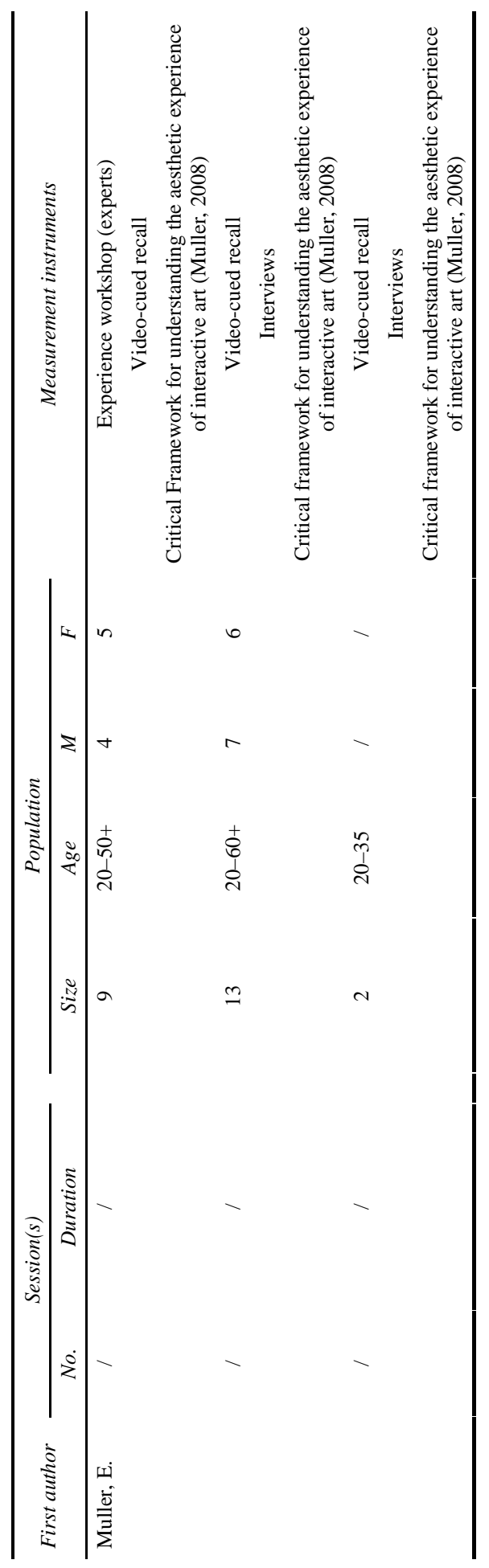


Table 3 Overview and documentation of the extracted artworks

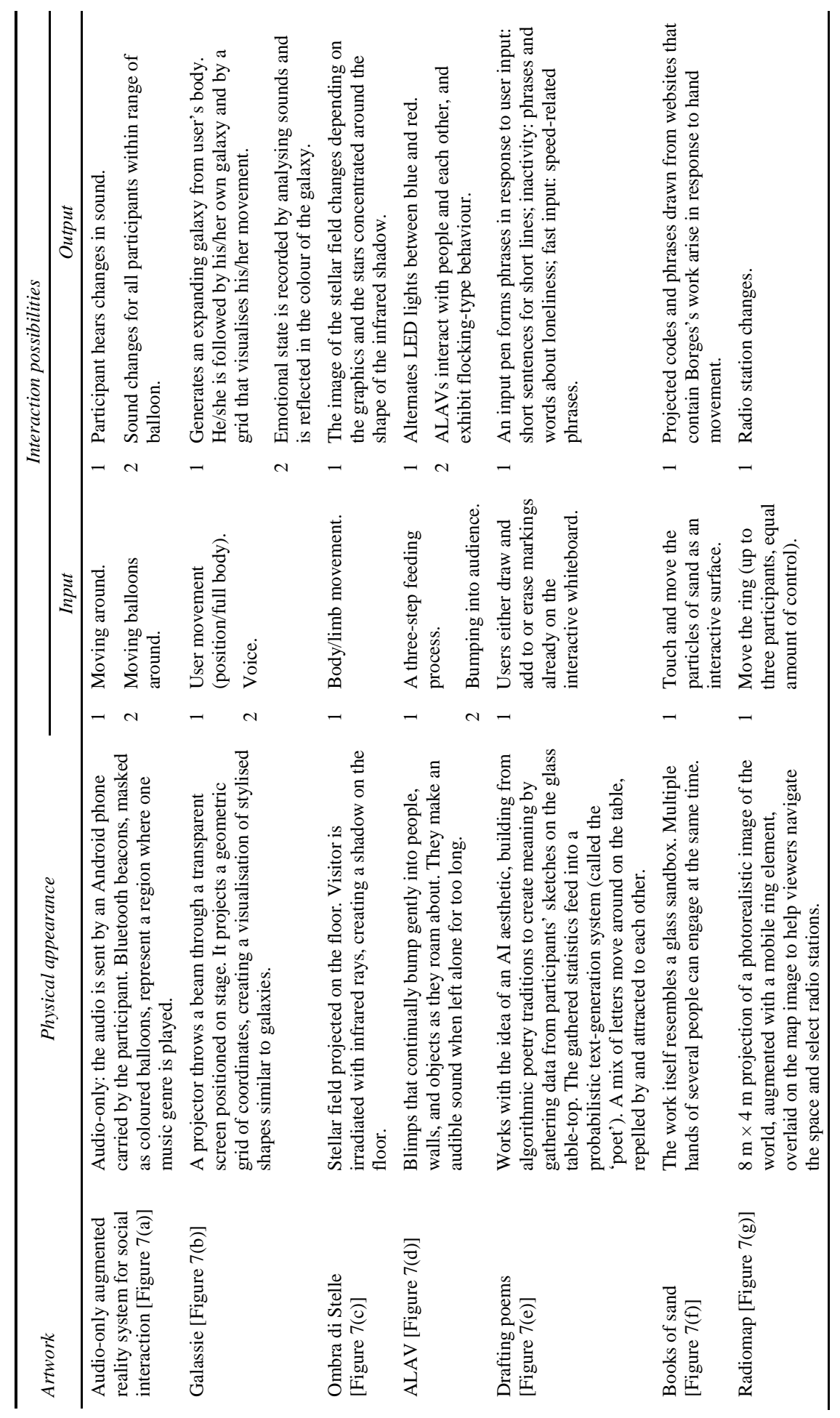


Table 3 Overview and documentation of the extracted artworks (continued)

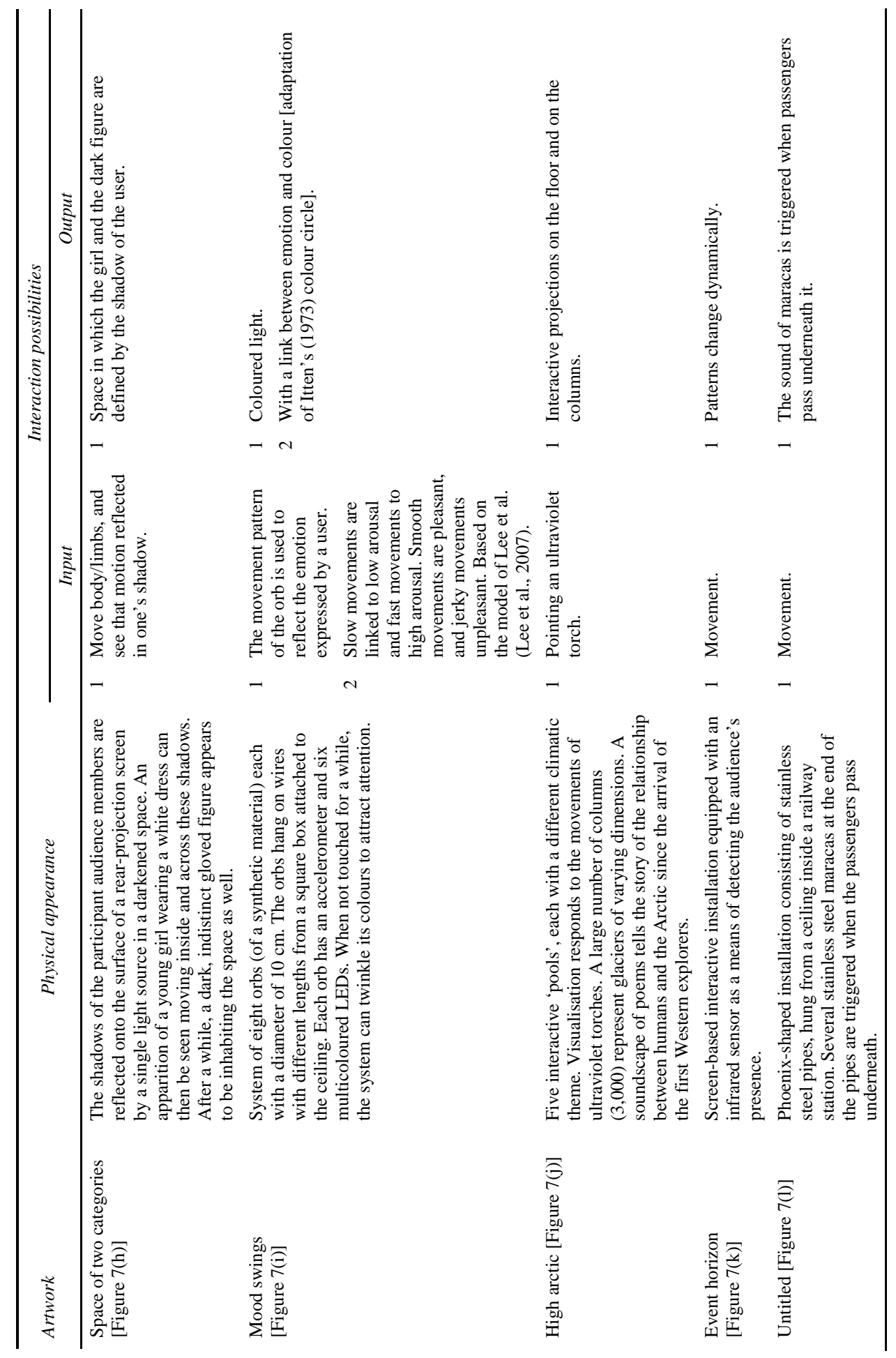


Table 3 Overview and documentation of the extracted artworks (continued)

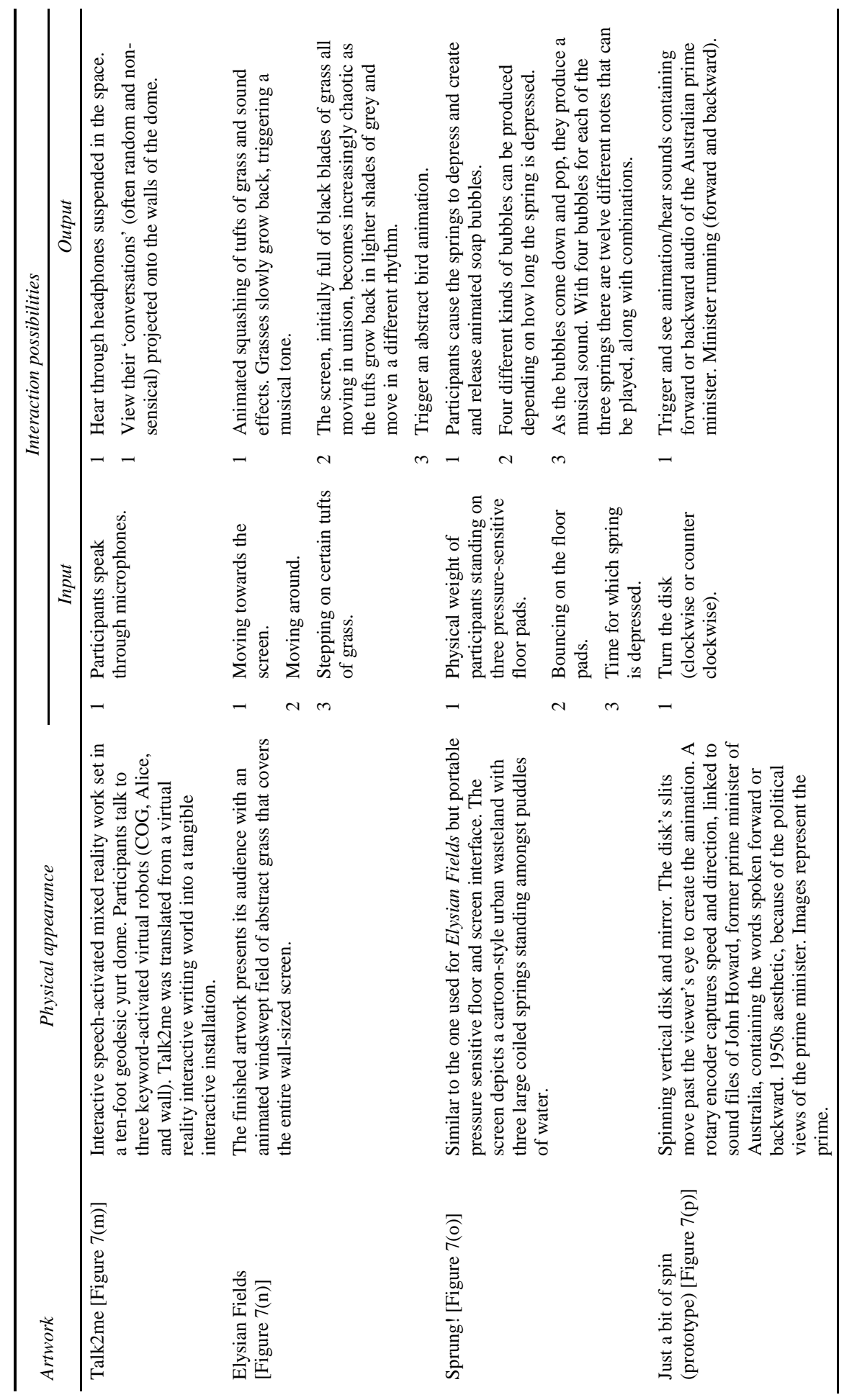


Table 3 Overview and documentation of the extracted artworks (continued)

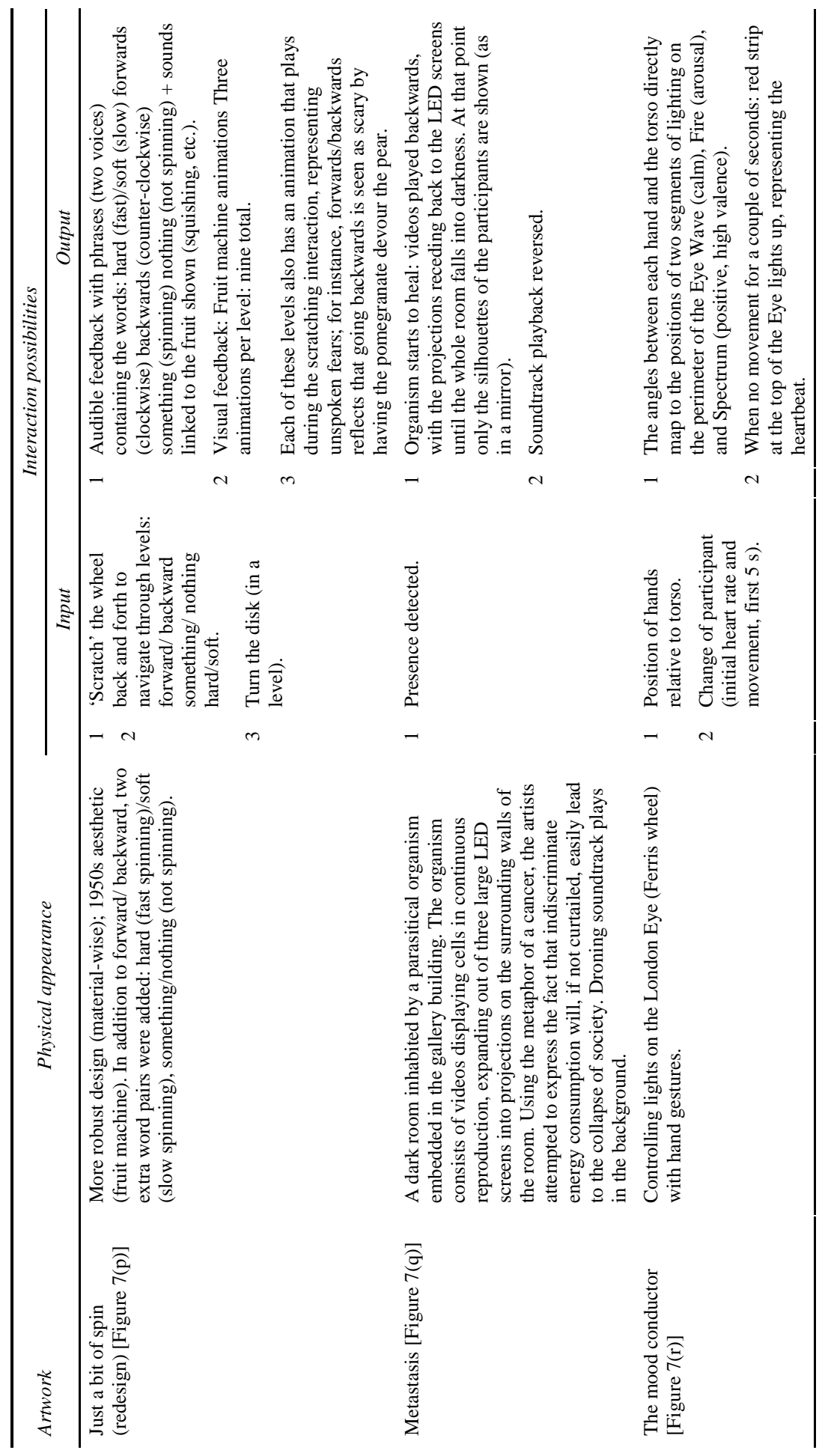


Table 3 Overview and documentation of the extracted artworks (continued)

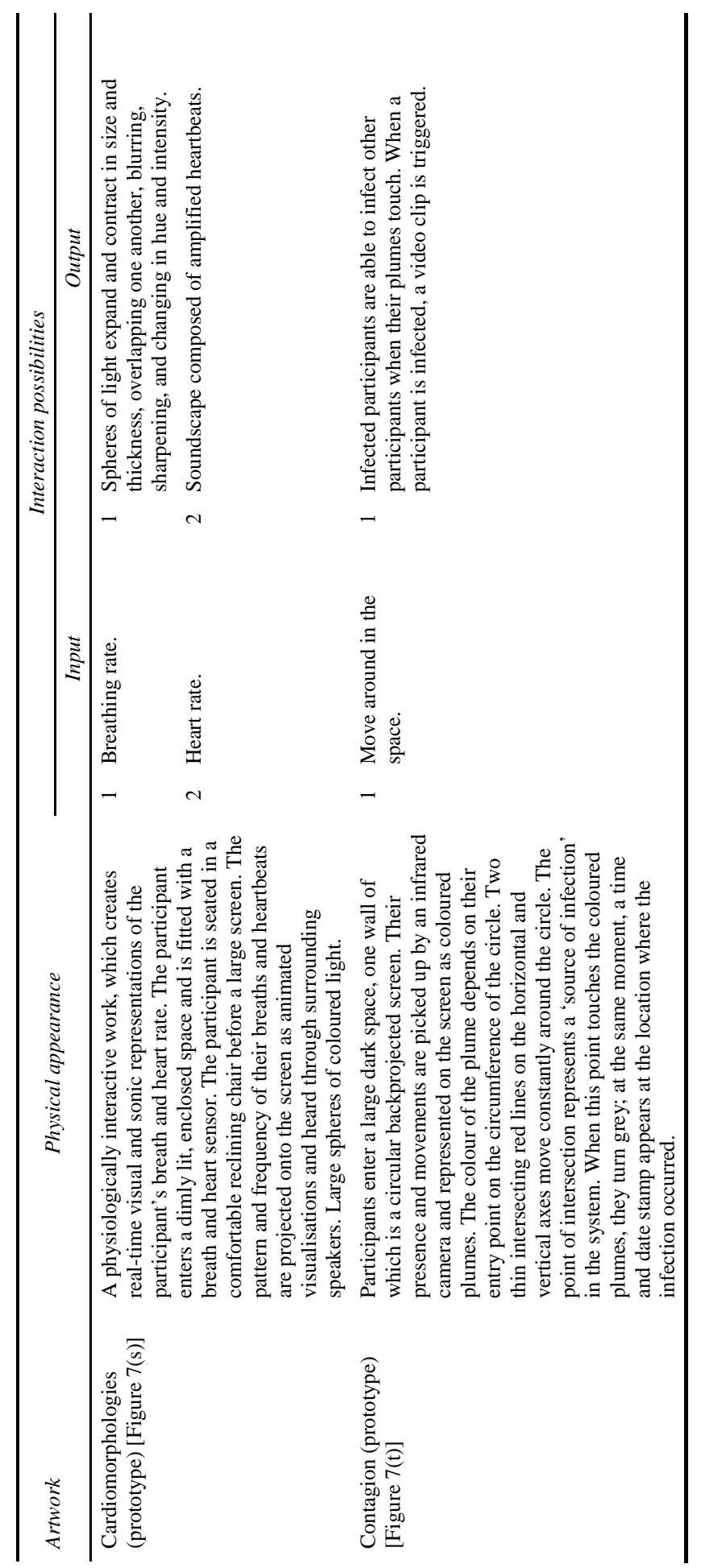


Figure 7 Visuals of extracted artworks, (a) audio-only augmented reality system for social interaction - Gurion and Jacoby (b) galassie - Studio Azzurro (c) Ombra di Stelle Studio Azzurro (d) autonomous light air vessels - Nikhil Mitter and Jed Berk (e) drafting poems: inverted potentialities - Eitan Mendowitz (f) books of sand Mariano Sardon (g) radiomap - Michael Hohl and Stephan Huber (h) space of two categories - Hanna Haaslahti (i) mood swings - Leticia Bialoskorski (j) high arctic UVA (k) event horizon - author unknown (l) untitled - author unknown (m) Talk2me Ann Morrison (N) Elysian Fields - Brigid Costello, Ian Gwilt and Dave Burraston (o) sprung! - Brigid Costello and Allistair Macinnes (p) just a bit of spin - Brigid Costello (q) metastasis - Luke Hespanhol (r) the mood conductor - Cinimod Studio (s) cardiomorphologies - George Khut (t) contagion - Gina Czarnecki (see online version for colours)
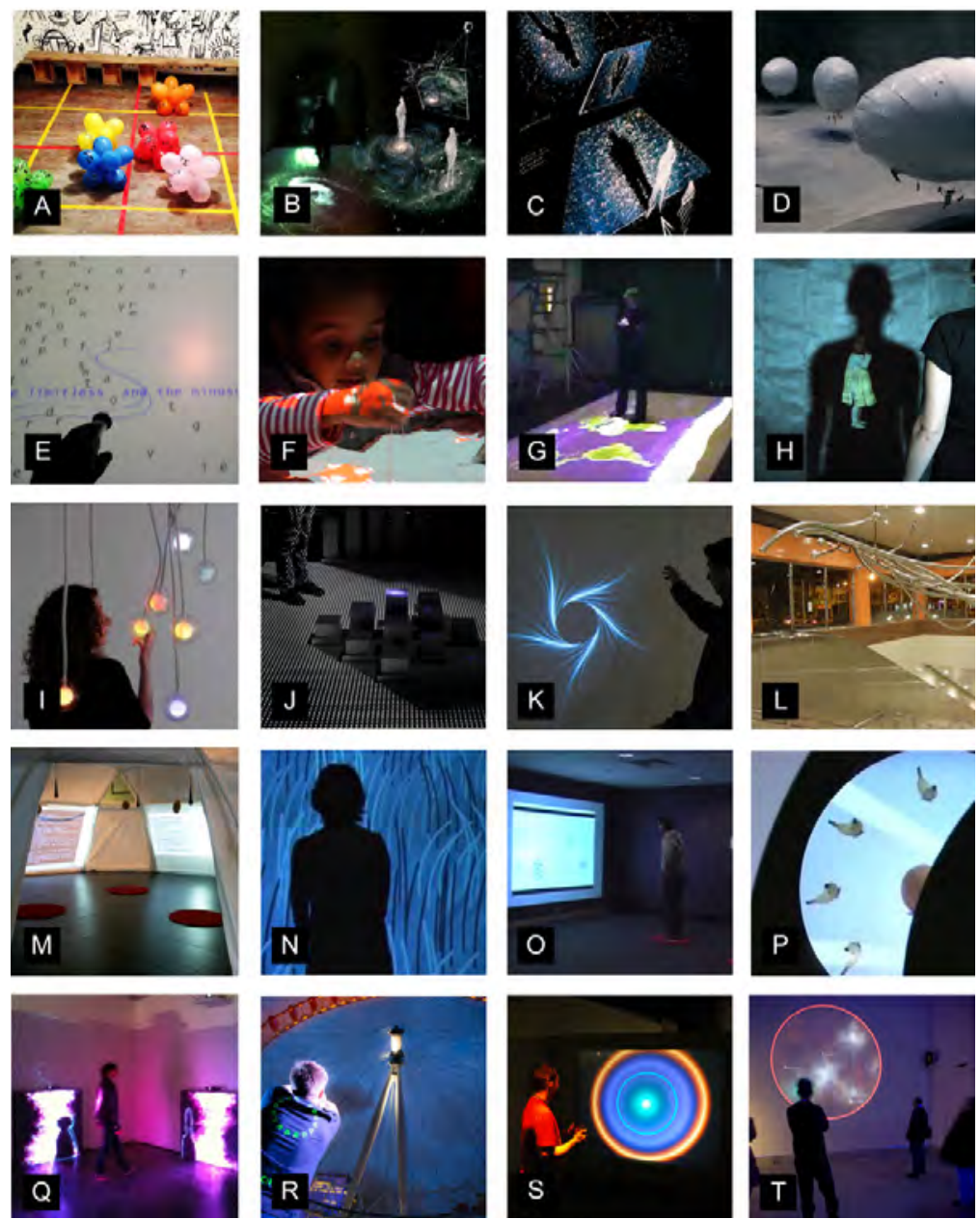
Figure 7 Visuals of extracted artworks, (a) audio-only augmented reality system for social interaction - Gurion and Jacoby (b) galassie - Studio Azzurro (c) Ombra di Stelle Studio Azzurro (d) autonomous light air vessels - Nikhil Mitter and Jed Berk (e) drafting poems: inverted potentialities - Eitan Mendowitz (f) books of sand Mariano Sardon (g) radiomap - Michael Hohl and Stephan Huber (h) space of two categories - Hanna Haaslahti (i) mood swings - Leticia Bialoskorski (j) high arctic UVA (k) event horizon - author unknown (l) untitled - author unknown (m) Talk2me Ann Morrison (N) Elysian Fields - Brigid Costello, Ian Gwilt and Dave Burraston (o) sprung! - Brigid Costello and Allistair Macinnes (p) just a bit of spin - Brigid Costello (q) metastasis - Luke Hespanhol (r) the mood conductor - Cinimod Studio (s) cardiomorphologies - George Khut (t) contagion - Gina Czarnecki (continued)
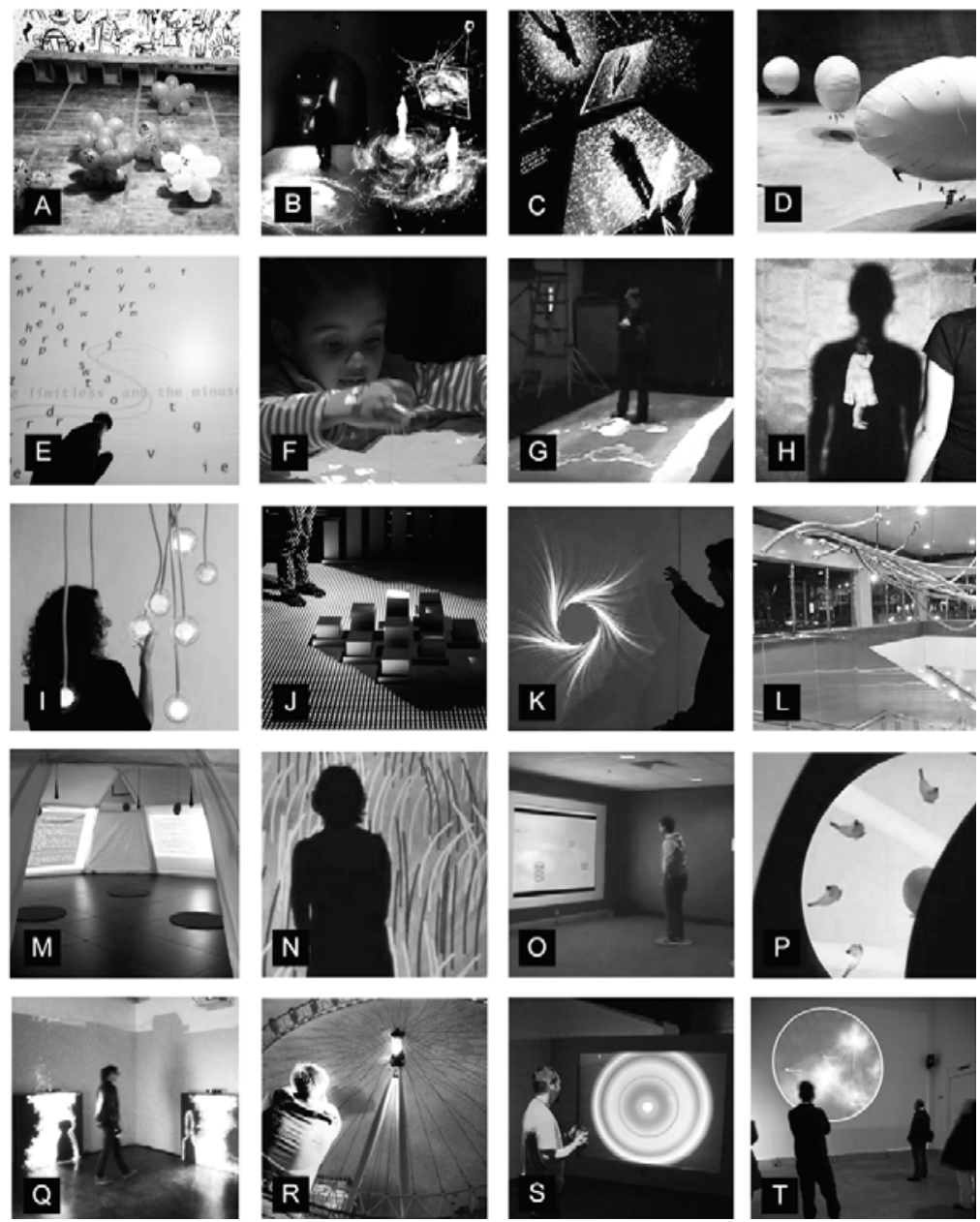

\subsection{Study population}

Most of the artworks studied ( $n=16$ ) were viewed by a population of between 2 and 60 people, ranging in age from under 16 to over 60 years, with an almost equal proportion of men and women. Four of the artworks had an unknown population of viewers. 


\subsection{Exhibition time}

For almost half of the artworks in the studies $(n=8)$ there was no data available about exhibition frequency and/or duration; three were shown only once. The exhibition times of the remaining artworks ( $n=6$ ) ranged from twice (two days) to one month.

\subsection{Measurement instruments}

All artworks were evaluated using mixed methods (2-5 per artwork). The most commonly used methods were (video) observation $(n=12)$, interviews $(n=12)$ and video-cued recall $(n=6)$.

\subsection{User responses}

\subsubsection{Human-artwork}

All the included articles involved human-to-artwork responses (Table 4), which can be divided into verbal, physical, and cognitive/emotional responses.

Table 4 Human-artwork responses

\begin{tabular}{|c|c|c|}
\hline Artwork & & Human-artwork response \\
\hline \multirow{2}{*}{$\begin{array}{l}\text { Audio-only } \\
\text { augmented reality } \\
\text { system for social } \\
\text { interaction } \\
\text { [Figure } 7(a) \text { ] }\end{array}$} & \multirow[t]{2}{*}{ Physical } & $\begin{array}{l}\text { Higher levels of movement (compared with behaviour of } \\
\text { other parties). }\end{array}$ \\
\hline & & $\begin{array}{l}\text { Higher level of change of location in space }(t(16)=1.7 \\
p=0.06)\end{array}$ \\
\hline \multirow[t]{6}{*}{$\begin{array}{l}\text { Galassie } \\
\text { [Figure } 7(b)], \text { Ombra } \\
\text { di Stelle [Figure } 7(\mathrm{c})]\end{array}$} & \multirow[t]{5}{*}{$\begin{array}{l}\text { Cognitive/ } \\
\text { emotional }\end{array}$} & $\begin{array}{l}\text { Positive and negative affect schedule (PANAS): POSITIVE } \\
(72 \times) \text { : interest (19), transport (19), ludic pleasure (11), } \\
\text { amazement (5), involvement (4), creation (4), serenity (4), } \\
\text { freedom (4), misc. (2): attentive, happy. NEGATIVE (26×): } \\
\text { confusion (6), irritation (4), indifference (4), frustration (3), } \\
\text { boredom (2), distressed (2), misc. (5): unsure, disquiet, } \\
\text { embarrassed, fear, loneliness. Positive affect: } 27.90 \\
(\mathrm{SD}=7.56) \text {, negative affect: } 12.62 \text { (SD 4.14). }\end{array}$ \\
\hline & & $\begin{array}{l}\text { Females scored higher on PA: } F=4.124, p=.045 . \text { No } \\
\text { significant gender difference on NA. }\end{array}$ \\
\hline & & $\begin{array}{l}\text { Significant effect of age for PA: } F=4.028, p=048 \text {. } \\
\text { Increasing the age of visitors increased the PA score } \\
\text { (regression } B=.120 \text { ). }\end{array}$ \\
\hline & & $\begin{array}{l}\text { Interest was provoked by curiosity, by the originality and } \\
\text { the unfamiliarity of the artwork, and by the attempt to } \\
\text { understand the way the artwork functions. }\end{array}$ \\
\hline & & $\begin{array}{l}\text { Feeling of control: } 54 \text { felt they were able to influence the } \\
\text { artworks, } 32 \text { felt the opposite (Ombra } n=44 \text {, Galassie } \\
n=42 \text { ); } 44 \text { answered that they were not controlled by the } \\
\text { artworks. Fifteen felt controlled by the system, and ten felt } \\
\text { dominated in the absence of feedback from the installation. }\end{array}$ \\
\hline & Misc. & Three major phases: circumspection, testing, play. \\
\hline
\end{tabular}


Table 4 Human-artwork responses (continued)

\begin{tabular}{|c|c|c|}
\hline Artwork & & Human-artwork response \\
\hline \multirow[t]{4}{*}{$\begin{array}{l}\text { ALAV } \\
\text { [Figure } 7(d)]\end{array}$} & Physical & $\begin{array}{l}\text { Gently patted or batted to move blimp on its way, away } \\
\text { from oneself, or towards others as a form of free-play. }\end{array}$ \\
\hline & & Pursued the ALAV (or returned to other activity). \\
\hline & $\begin{array}{l}\text { Cognitive/ } \\
\text { emotional }\end{array}$ & Role of 'feeder'. \\
\hline & Misc. & Interactive play. \\
\hline \multirow[t]{7}{*}{$\begin{array}{l}\text { Drafting poems } \\
\text { [Figure } 7(\mathrm{e})]\end{array}$} & Verbal & $\begin{array}{l}\text { 'I only got sad words, what does it mean?' 'I can never } \\
\text { catch the letters, they move too fast and then they mock me } \\
\text { with phrases about speediness'. }\end{array}$ \\
\hline & Physical & Tried to mimic results/test theories of how it worked. \\
\hline & & $\begin{array}{l}\text { Sensual motions building and/or erasing with flowing } \\
\text { motions. }\end{array}$ \\
\hline & & Larger-than-life, exaggerated motions. \\
\hline & & Embodied play. \\
\hline & $\begin{array}{l}\text { Cognitive/ } \\
\text { emotional }\end{array}$ & Tried to mimic results/test theories of working. \\
\hline & Misc. & Interactive play. \\
\hline \multirow{9}{*}{$\begin{array}{l}\text { Books of sand } \\
\text { [Figure } 7(f)]\end{array}$} & Verbal & Verbal play. \\
\hline & & Pointed while reading aloud. \\
\hline & & Exclaimed phrases read. \\
\hline & Physical & Embodied play. \\
\hline & & More sensual, more considered slower-paced movements. \\
\hline & & Made deictic gestures/pointed while reading aloud. \\
\hline & Cognitive/e & Mesmerised. \\
\hline & motional & Reflection. \\
\hline & & $\begin{array}{l}\text { Quieter/more reflective and more sensually engaged when } \\
\text { observing and interacting. }\end{array}$ \\
\hline \multirow{8}{*}{$\begin{array}{l}\text { Radiomap } \\
\text { [Figure } 7(\mathrm{~g}) \text { ] }\end{array}$} & Physical & Experiencing space. \\
\hline & & Experiencing the body. \\
\hline & & 'This is not a room'. \\
\hline & Cognitive/e & Orientation was dominant experience. \\
\hline & motional & Exploring the map was secondary to exploring the interface. \\
\hline & & $\begin{array}{l}\text { Action and response had to be real-time. Otherwise, } \\
\text { experience was lost. }\end{array}$ \\
\hline & & $\begin{array}{l}\text { Mental images: 'lost track of time', 'live experience', 'this } \\
\text { is live and ... now'. }\end{array}$ \\
\hline & & $\begin{array}{l}\text { Global awareness (eight visitors), interconnectedness, } \\
\text { Weltanschauung. }\end{array}$ \\
\hline
\end{tabular}


Table 4 Human-artwork responses (continued)

\begin{tabular}{|c|c|c|}
\hline Artwork & & Human-artwork response \\
\hline \multirow{14}{*}{$\begin{array}{l}\text { Space of two } \\
\text { categories } \\
\text { [Figure } 7(\mathrm{~h})]\end{array}$} & \multirow[t]{9}{*}{ Physical } & $\begin{array}{l}\text { Pure enjoyment generated through their gestural 'dance' } \\
\text { with the child. }\end{array}$ \\
\hline & & $\begin{array}{l}\text { Others asked for more control. Example: 'the impression } \\
\text { that the girl moved along with you, according to your } \\
\text { movement'; wanted to 'make the girl do different things } \\
\text { depending on your moves/shape'; 'the interaction with the } \\
\text { girl is too limited'. }\end{array}$ \\
\hline & & Pleasure in the use of a gestural interface. \\
\hline & & Moved around in the room. \\
\hline & & Moved in and out of the projection area. \\
\hline & & Moved back and forth. \\
\hline & & Moved faster and slower. \\
\hline & & $\begin{array}{l}\text { Tried different combinations of movements (= not reported } \\
\text { in writing, as if it were insignificant or irrelevant. Just } \\
\text { 'mucking around'). }\end{array}$ \\
\hline & & $\begin{array}{l}\text { Participants acted as though the interaction started at the } \\
\text { moment of understanding. }\end{array}$ \\
\hline & \multirow[t]{5}{*}{$\begin{array}{l}\text { Cognitive/ } \\
\text { emotional }\end{array}$} & $\begin{array}{l}\text { Concerns for welfare and agency of the child. Strongly } \\
\text { ambivalent: some simply enjoyed the movement of the } \\
\text { child, while others expressed mild to strong concern over } \\
\text { her welfare. }\end{array}$ \\
\hline & & $\begin{array}{l}\text { Some did not appear to react as strongly to the intended } \\
\text { reflective aspects as others. These participants mostly } \\
\text { discussed the 'technology' involved in the work. }\end{array}$ \\
\hline & & $\begin{array}{l}\text { Participants who had difficulties with the interactivity or } \\
\text { finding logic in the work seemed to offer up technical } \\
\text { solutions more readily than those who engaged with the } \\
\text { philosophy. }\end{array}$ \\
\hline & & $\begin{array}{l}\text { Participants who visit galleries regularly tended to reflect on } \\
\text { the meaning of the work more. They saw the gloved hand } \\
\text { (suspension of disbelief). Others did not. }\end{array}$ \\
\hline & & $\begin{array}{l}\text { In general, people underestimated the time spent in the } \\
\text { installation (perception v. observation). }\end{array}$ \\
\hline \multirow{6}{*}{$\begin{array}{l}\text { Mood swings } \\
\text { (session 1) } \\
\text { [Figure 7(i)] }\end{array}$} & \multirow[t]{4}{*}{ Physical } & Very cautious, after two types of interaction: \\
\hline & & $\begin{array}{l}1 \text { some tried out different motions after being cautious, } \\
\text { creating a lot of colours }\end{array}$ \\
\hline & & 2 some remained cautious, thus creating only two colours. \\
\hline & & $\begin{array}{l}\text { Swinging, squeezing, touching, tickling, stroking, hitting, } \\
\text { and braiding the orb. }\end{array}$ \\
\hline & \multirow{2}{*}{$\begin{array}{l}\text { Cognitive/ } \\
\text { emotional }\end{array}$} & 75\% discovered link between movement and colour. \\
\hline & & 35\% saw link between installation and emotion. \\
\hline
\end{tabular}


Table 4 Human-artwork responses (continued)

\begin{tabular}{|c|c|c|}
\hline Artwork & & Human-artwork response \\
\hline \multirow[t]{8}{*}{$\begin{array}{l}\text { Mood swings } \\
\text { (session 2) } \\
\text { [Figure 7(i)] }\end{array}$} & Verbal & $\begin{array}{l}\text { 25\% mentioned words linked to emotion in relation to the } \\
\text { installation (during interaction and questionnaire): 'the } \\
\text { spheres express themselves', 'calm', 'aggression', and } \\
\text { 'soothing'. }\end{array}$ \\
\hline & & $\begin{array}{l}\text { Most participants commented on the functioning of the } \\
\text { installation, not their own thoughts or feelings. }\end{array}$ \\
\hline & Physical & $\begin{array}{l}\text { All but two reached the control phase (avg. } 2.8 \text { times per } \\
\text { session). }\end{array}$ \\
\hline & & $\begin{array}{l}\text { Participants tried to manipulate the device. A common } \\
\text { approach involved making it into a game, for instance by } \\
\text { trying to light all the orbs in the same colour. }\end{array}$ \\
\hline & $\begin{array}{l}\text { Cognitive/ } \\
\text { emotional }\end{array}$ & $\begin{array}{l}\text { All reached the response phase ( } 2.8 \text { times per session), and } \\
\text { figured out that the installation works on movement. } \\
\text { Important moment was seeing multiple colours. Theories } \\
\text { were formed as to how the installation works ( } 45 \% \\
\text { individual, } 67 \% \text { group). }\end{array}$ \\
\hline & & $\begin{array}{l}9 \% \text { of individuals and } 17 \% \text { of groups reached the } \\
\text { contemplation phase, in which they reflected upon the } \\
\text { meaning communicated. }\end{array}$ \\
\hline & & $\begin{array}{l}\text { None reached the belonging phase, in which the participant } \\
\text { feels controlled by the artwork. It affects the viewers, in a } \\
\text { closed loop of emotional interaction. }\end{array}$ \\
\hline & & Disengagement phase: $50 \%$ ended in a state of control. \\
\hline \multirow[t]{3}{*}{$\begin{array}{l}\text { High arctic } \\
\text { [Figure } 7(\mathrm{j})]\end{array}$} & Physical & $\begin{array}{l}\text { Wave, circle, point, oscillating movements, all of which } \\
\text { contributed differing lengths and frequencies of actions. }\end{array}$ \\
\hline & Misc. & $\begin{array}{l}\text { The longer people spent investigating the content and its } \\
\text { manipulation through various movements of the ultraviolet } \\
\text { torch, the more productive and, thus, the more engaged } \\
\text { became the interaction session. }\end{array}$ \\
\hline & & $\begin{array}{l}\text { People who chose to wander through with little or no } \\
\text { exploration of the projections raise the question of whether } \\
\text { they were engaged in any sustained manner. Yet quite } \\
\text { frequently, visitors immersed in some aspect of the } \\
\text { installation would sit or stand still. This is a form of implicit } \\
\text { interaction and thus engagement. }\end{array}$ \\
\hline \multirow[t]{4}{*}{$\begin{array}{l}\text { Event horizon } \\
\text { [Figure } 7(\mathrm{k})]\end{array}$} & Physical & $\begin{array}{l}\text { Waved hands, shook feet, moved back and forth, and some } \\
\text { danced. }\end{array}$ \\
\hline & $\begin{array}{l}\text { Cognitive/ } \\
\text { emotional }\end{array}$ & $\begin{array}{l}\text { 95\% of participants reported that the interactive effect } \\
\text { stimulated their curiosity, and that the shifting sounds and } \\
\text { image patterns held their attention and made them want to } \\
\text { explore and try to understand how it worked. }\end{array}$ \\
\hline & & $\begin{array}{l}90 \% \text { indicated that they were trying to discover how the } \\
\text { installation worked and actively interacted with the } \\
\text { installation. }\end{array}$ \\
\hline & & $\begin{array}{l}\text { 95\% were excited or interested (when learning movement } \\
\text { trigger patterns). }\end{array}$ \\
\hline
\end{tabular}


Table 4 Human-artwork responses (continued)

\begin{tabular}{|c|c|c|}
\hline Artwork & & Human-artwork response \\
\hline \multirow[t]{2}{*}{$\begin{array}{l}\text { Event horizon } \\
\text { [Figure } 7(\mathrm{k})]\end{array}$} & \multirow[t]{2}{*}{ Misc. } & $\begin{array}{l}\text { The non-repeated sounds engaged the viewers initially; } \\
\text { together with changing patterns this evoked interactor } \\
\text { curiosity and led to further exploration. }\end{array}$ \\
\hline & & $\begin{array}{l}\text { The sound and image patterns of the works were constantly } \\
\text { changing as people passed the installation, and as such, it } \\
\text { did not require any active physical intervention to trigger an } \\
\text { initial interaction, but instantly drew people's attention. As } \\
\text { the interactors realised that they were the stimulus } \\
\text { triggering the interaction, they instantly became involved, } \\
\text { and enjoyed this creative authorship. }\end{array}$ \\
\hline \multirow[t]{3}{*}{$\begin{array}{l}\text { Untitled } \\
\text { [Figure 7(l)] }\end{array}$} & Physical & $\begin{array}{l}\text { None of the physical reactions mentioned above were } \\
\text { exhibited by passengers. }\end{array}$ \\
\hline & \multirow{2}{*}{$\begin{array}{l}\text { Cognitive/ } \\
\text { emotional }\end{array}$} & Curiosity at first; but this effect did not endure. \\
\hline & & $\begin{array}{l}\text { Passengers were not so active, but all gave positive } \\
\text { responses. }\end{array}$ \\
\hline \multirow[t]{7}{*}{$\begin{array}{l}\text { Talk2me } \\
\text { [Figure } 7(\mathrm{~m})]\end{array}$} & \multirow[t]{2}{*}{ Verbal } & $\begin{array}{l}\text { Mode of coresponders: responded back to others and the } \\
\text { robots. }\end{array}$ \\
\hline & & $\begin{array}{l}\text { Engaged interactors (invested in an embodied way and } \\
\text { committed themselves both to the space and to the } \\
\text { interaction afforded there). }\end{array}$ \\
\hline & \multirow[t]{2}{*}{ Physical } & Mode of 'perchers': sat down and engaged. \\
\hline & & $\begin{array}{l}\text { Deictic gesturing (used hands to point towards the screen or } \\
\text { towards headphones). }\end{array}$ \\
\hline & \multirow[t]{3}{*}{$\begin{array}{l}\text { Cognitive/ } \\
\text { emotional }\end{array}$} & $\begin{array}{l}\text { Observers: passively watched the activity and/or listened in } \\
\text { on the discussion. }\end{array}$ \\
\hline & & Comprehension. \\
\hline & & Speculation. \\
\hline \multirow[t]{6}{*}{$\begin{array}{l}\text { Elysian Fields } \\
\text { [Figure 7(n)] }\end{array}$} & Physical & $\begin{array}{l}\text { Stomped their feet as if they were actually using force to } \\
\text { crush something (supported by the sound it made). }\end{array}$ \\
\hline & \multirow{5}{*}{$\begin{array}{l}\text { Cognitive/ } \\
\text { emotional }\end{array}$} & Sound of snow triggering memories of childhood. \\
\hline & & Sound evoking a physical sensation. \\
\hline & & $\begin{array}{l}\text { Pleasurable tension between having direct immediate } \\
\text { control and feeling like the work had a life of its own. }\end{array}$ \\
\hline & & $\begin{array}{l}\text { Feeling a presence/entity along in there with them } \\
\text { (camaraderie/intimacy). }\end{array}$ \\
\hline & & 'Immersed: completely 'in the world’'. \\
\hline \multirow{4}{*}{$\begin{array}{l}\text { Sprung! } \\
\text { [Figure } 7(0)]\end{array}$} & \multirow[t]{4}{*}{ Physical } & Only the most playful and unselfconscious: \\
\hline & & 1 leaped about and jumped \\
\hline & & $\begin{array}{l}2 \text { tried to depress the three springs at once (using } \\
\text { knees/hands) }\end{array}$ \\
\hline & & $\begin{array}{l}3 \text { felt childlike and free to move in physically pleasing } \\
\text { ways - partners enjoyed watching them do this. }\end{array}$ \\
\hline
\end{tabular}


Table 4 Human-artwork responses (continued)

\begin{tabular}{|c|c|c|}
\hline Artwork & & Human-artwork response \\
\hline \multirow[t]{5}{*}{$\begin{array}{l}\text { Sprung! } \\
\text { [Figure } 7(0)]\end{array}$} & $\begin{array}{l}\text { Cognitive/ } \\
\text { emotional }\end{array}$ & $\begin{array}{l}\text { Simulation of the real world (so not immersed in another } \\
\text { world). }\end{array}$ \\
\hline & & $\begin{array}{l}\text { Expectation that it would perform as a musical instrument } \\
\text { was not met: frustration (mostly among those with musical } \\
\text { experience). }\end{array}$ \\
\hline & & $\begin{array}{l}\text { "I think the spinning wheel was fascinating and fun and } \\
\text { then that would have been it, it would have been interesting } \\
\text { and then I would have fully explored it and that would have } \\
\text { been the end of it". }\end{array}$ \\
\hline & & $\begin{array}{l}\text { "I couldn't change it as much as I would possibly be able to } \\
\text { change the other ones". }\end{array}$ \\
\hline & & $\begin{array}{l}\text { "What I was seeing and what I was listening to didn't really } \\
\text { feel related to me". }\end{array}$ \\
\hline $\begin{array}{l}\text { Just a bit of spin } \\
\text { (prototype) } \\
\text { [Figure } 7(\mathrm{p})]\end{array}$ & & $\mathrm{n} / \mathrm{a}$ \\
\hline \multirow[t]{11}{*}{$\begin{array}{l}\text { Just a bit of spin } \\
\text { (redesign) } \\
\text { [Figure } 7(\mathrm{p})]\end{array}$} & Physical & $\begin{array}{l}\text { Sensation: “there was a sensibility about it, and warmth } \\
\text { about it, that this one doesn't have, it was cardboard, and } \\
\text { had the little paper flaps or something. I kind of liked that, } \\
\text { and it created a breeze, this doesn't have air movement with } \\
\text { it as well”. }\end{array}$ \\
\hline & & $\begin{array}{l}\text { "The physical was purely the means, and yeah, it was fun, } \\
\text { but I didn’t [rate] it the highest, because by doing that, } \\
\text { that's the means to discovering, and working it out, that's } \\
\text { what was the enjoyable part”. }\end{array}$ \\
\hline & & $4 / 22$ did not enjoy the sensual aspects of the work. \\
\hline & & $\begin{array}{l}\text { "I found this really sensitive, so you know, I could just like } \\
\text { go to nothing, and it was still doing something, so that was } \\
\text { really good". }\end{array}$ \\
\hline & $\begin{array}{l}\text { Cognitive/ } \\
\text { emotional }\end{array}$ & $\begin{array}{l}\text { Playful and explorative (10/30): all but two discovered how } \\
\text { to mix and explored more than one level (one to three } \\
\text { minutes in the space). }\end{array}$ \\
\hline & & $\begin{array}{l}\text { Enthusiastic (6/30): everyone mixed and fully explored at } \\
\text { least two levels - half of them all three (three to eight } \\
\text { minutes in the space). Experience that closely matched the } \\
\text { artistic aims of the piece. }\end{array}$ \\
\hline & & $\begin{array}{l}\text { Personal connections that people made resulted in a more } \\
\text { enthusiastic experience. }\end{array}$ \\
\hline & & Feeling of incompetence/insecurity. \\
\hline & & Subversion: \\
\hline & & $\begin{array}{l}1 \text { "it was nice to be empowered, to have some element of } \\
\text { control over the politicians" }\end{array}$ \\
\hline & & $\begin{array}{l}2 \text { "I like this innocuous piece of fruit being used in } \\
\text { relation to these words, and this very serious monotone } \\
\text {... I felt like there was a nice pattern to the fruit, and } \\
\text { then that stuff I was doing was making it a bit more } \\
\text { messy and mixing them up". }\end{array}$ \\
\hline
\end{tabular}


Table 4 Human-artwork responses (continued)

\begin{tabular}{|c|c|c|}
\hline Artwork & & Human-artwork response \\
\hline \multirow[t]{5}{*}{$\begin{array}{l}\text { Just a bit of spin } \\
\text { (redesign) } \\
\text { [Figure } 7(\mathrm{p})]\end{array}$} & \multirow[t]{3}{*}{$\begin{array}{l}\text { Cognitive/ } \\
\text { emotional }\end{array}$} & $\begin{array}{l}\text { Subversion negative: “it wasn’t real stuff, so I wasn't } \\
\text { subverting anything. Maybe if it was John Howard's voice } \\
\text { [in real life], and I was making him say different things...” }\end{array}$ \\
\hline & & Cut off: 'repetition in words: I stopped listening’. \\
\hline & & $\begin{array}{l}\text { Captivation: } 24 \text {, creation: } 30 \text {, danger: } 2 \text {, difficulty: } 25 \text {, } \\
\text { discovery: } 29 \text {, exploration: } 28 \text {, fantasy: } 13 \text {, sensation: } 18 \text {, } \\
\text { simulation: } 13 \text {, subversion: } 24 \text {, sympathy: } 14 \text {. }\end{array}$ \\
\hline & \multirow[t]{2}{*}{ Misc. } & $\begin{array}{l}\text { Group uninterested ( } 4 / 30) \text { : entered the space and turned the } \\
\text { wheel in one direction only. }\end{array}$ \\
\hline & & $\begin{array}{l}\text { Group mildly curious (10/30): half of this group turned the } \\
\text { wheel in both directions, but none discovered how to mix } \\
\text { and reach another level. Spent one to two minutes } \\
\text { interacting with the work. }\end{array}$ \\
\hline \multirow{8}{*}{$\begin{array}{l}\text { Metastasis } \\
\text { [Figure 7(q)] }\end{array}$} & \multirow[t]{3}{*}{ Physical } & Two groups: \\
\hline & & $\begin{array}{l}1 \text { performers: those mediating the collective experience by } \\
\text { overcoming their own personal concerns about public } \\
\text { embarrassment }\end{array}$ \\
\hline & & $\begin{array}{l}2 \text { spectators: those reluctant to cross the threshold from } \\
\text { 'focal awareness' to 'participation', instead passively } \\
\text { enjoying the experience by observing the performers } \\
\text { onstage. }\end{array}$ \\
\hline & \multirow[t]{5}{*}{$\begin{array}{l}\text { Cognitive/ } \\
\text { emotional }\end{array}$} & $\begin{array}{l}\text { 7/13 reported consciously trying to make sense of it by } \\
\text { themselves; the others experienced the interaction with } \\
\text { someone else already inside. Strikingly, those five failed to } \\
\text { make sense of the work even after the other person had left } \\
\text { the room (only reported by one, who was in there alone). }\end{array}$ \\
\hline & & $\begin{array}{l}\text { Five reported it as some kind of delight: sought to } \\
\text { appreciate the work and engage with it at an emotional } \\
\text { level, rather than necessarily trying to make sense of it; } \\
\text { experienced the interaction on their own. }\end{array}$ \\
\hline & & $\begin{array}{l}\text { 9/13 reported sound in relation to general feeling of } \\
\text { comfort, pleasantness, relaxation, or enjoyment, or to being } \\
\text { inside a large whale/womb: these were all people who were } \\
\text { alone in the space. }\end{array}$ \\
\hline & & $\begin{array}{l}\text { 5/13 explicitly pointed out that the experience was better } \\
\text { when they were allowed to have it in privacy. }\end{array}$ \\
\hline & & $\begin{array}{l}\text { Reasons not to engage: feeling self-conscious, shy, } \\
\text { uncomfortable, not wanting to disrupt anyone else's } \\
\text { experience. }\end{array}$ \\
\hline \multirow[t]{2}{*}{$\begin{array}{l}\text { The mood conductor } \\
\text { [Figure } 7(\mathrm{r}) \text { ] }\end{array}$} & \multirow[t]{2}{*}{ Physical } & $\begin{array}{l}\text { Spatial analysis: X-Y plane: outstretched arm movement in } \\
\text { a semi-circular pathway, pivoting at the shoulder. Z-Y } \\
\text { plane: little variation in depth; much more restricted for left } \\
\text { hand (suggesting handedness influence). }\end{array}$ \\
\hline & & $\begin{array}{l}\text { Physiological and kinematic analysis: high degree of } \\
\text { synchrony in timing of the movements of left and right } \\
\text { hands. }\end{array}$ \\
\hline
\end{tabular}


Table 4 Human-artwork responses (continued)

\begin{tabular}{|c|c|c|}
\hline Artwork & & Human-artwork response \\
\hline \multirow[t]{3}{*}{$\begin{array}{l}\text { The mood conductor } \\
\text { [Figure } 7(\mathrm{r})]\end{array}$} & \multirow[t]{3}{*}{ Physical } & $\begin{array}{l}\text { Angle of movement: in phase or out of phase, } \\
\text { corresponding to symmetrical and non-symmetrical } \\
\text { movement. }\end{array}$ \\
\hline & & $\begin{array}{l}\text { Links between behaviour and content style: Wave (hand } \\
\text { data: } 104 \text { people, heart rate data: } 29 \text { people): calm style of } \\
\text { interaction, spectrum (hand data: } 133 \text { people, heart rate } \\
\text { data: } 42 \text { people): more energetic behaviour (higher average } \\
\text { heart rate and hand velocity), fire (hand data: } 111 \text { people, } \\
\text { heart rate data: } 34 \text { people): highest average hand position. }\end{array}$ \\
\hline & & $\begin{array}{l}\text { Gestural analysis: propellers, sway, flag, seesaw, hands } \\
\text { together, angel, } 270^{\circ} \text {, traffic control, wave, wheel. }\end{array}$ \\
\hline \multirow{18}{*}{$\begin{array}{l}\text { Cardiomorphologies } \\
\text { (prototype) } \\
\text { [Figure } 7(\mathrm{~s})]\end{array}$} & \multirow[t]{6}{*}{ Physical } & Felt the visualisations closely reflected her breathing. \\
\hline & & Tried to make them smoother by slowing down her breath. \\
\hline & & $\begin{array}{l}\text { Hearing and seeing her heart stimulated panic sensations in } \\
\text { her body. }\end{array}$ \\
\hline & & $\begin{array}{l}\text { Fascinated by the way the rings reflected her breathing, she } \\
\text { immediately started to manipulate her breath, to try out } \\
\text { different things and see the visual effects. }\end{array}$ \\
\hline & & $\begin{array}{l}\text { Felt her physical sensations were very integrated with the } \\
\text { visuals. }\end{array}$ \\
\hline & & $\begin{array}{l}\text { Tried to influence the patterns by exaggerating his } \\
\text { breathing, holding his breath, and then breathing fast. }\end{array}$ \\
\hline & \multirow{12}{*}{$\begin{array}{l}\text { Emotional } \\
\text { mental }\end{array}$} & Able to interpret the visual information. \\
\hline & & $\begin{array}{l}\text { Reported memories, triggered by the experience, of times in } \\
\text { his life where he had measured or experimented with his } \\
\text { pulse. }\end{array}$ \\
\hline & & The ring visualisation was very relaxing - recalling yoga. \\
\hline & & Experimented with different visualisations. \\
\hline & & Found it beautiful and mesmerising. \\
\hline & & $\begin{array}{l}\text { Something internal to her is being projected externally, } \\
\text { making her feel emotional. }\end{array}$ \\
\hline & & Found the visuals very beautiful and absorbing. \\
\hline & & $\begin{array}{l}\text { Thought about an operation she was meant to have on her } \\
\text { heart as a child. }\end{array}$ \\
\hline & & $\begin{array}{l}\text { Spent some time focusing on her breathing and relaxation } \\
\text { and then began to experiment with different thoughts; she } \\
\text { saw a reaction to the installation. }\end{array}$ \\
\hline & & $\begin{array}{l}\text { At times she noted with curiosity that the visualisations } \\
\text { were doing things that surprised her. }\end{array}$ \\
\hline & & $\begin{array}{l}\text { Tried to exaggerate a feeling of tension, by pretending to } \\
\text { himself that it is a terrible experience. He tried to do some } \\
\text { difficult maths in his head. }\end{array}$ \\
\hline & & $\begin{array}{l}\text { Finally he thought of his girlfriend, whom he had not seen } \\
\text { in three weeks, and saw a big response in the system. }\end{array}$ \\
\hline
\end{tabular}


Table 4 Human-artwork responses (continued)

\begin{tabular}{|c|c|c|}
\hline Artwork & & Human-artwork response \\
\hline \multirow{15}{*}{$\begin{array}{l}\text { Contagion } \\
\text { (prototype) } \\
{[\text { Figure } 7(\mathrm{t})]}\end{array}$} & \multirow[t]{7}{*}{ Physical } & $\begin{array}{l}\text { Realised that the work is responding to movement and } \\
\text { experimented for a while. }\end{array}$ \\
\hline & & Felt as though being 'watched'. \\
\hline & & Tried to intersect with the crosshairs. \\
\hline & & $\begin{array}{l}\text { Stepped in and out of the circle to see if he could change it } \\
\text { is colour. }\end{array}$ \\
\hline & & $\begin{array}{l}\text { Experimented with changing his clothing and hair to see the } \\
\text { reaction in the mirror screen. }\end{array}$ \\
\hline & & $\begin{array}{l}\text { Tried to write her name in the colour palette and tested the } \\
\text { effects of different kinds of movement and how they affect } \\
\text { the visuals. }\end{array}$ \\
\hline & & $\begin{array}{l}\text { Fascinated by the way the visuals responded to her actions } \\
\text { in the mirror and colour palette. }\end{array}$ \\
\hline & \multirow{8}{*}{$\begin{array}{l}\text { Emotional } \\
\text { mental }\end{array}$} & Saw no connection to disease or contagion. \\
\hline & & He believed the face to be static. \\
\hline & & Most absorbed by this image. \\
\hline & & $\begin{array}{l}\text { Time working out the position of the camera and the } \\
\text { boundaries of the interactive space. }\end{array}$ \\
\hline & & She interpreted the face as representing disease. \\
\hline & & The fast reaction time and visual effects of the mirror. \\
\hline & & Fascinated. \\
\hline & & Intriguing. \\
\hline \multirow[t]{10}{*}{$\begin{array}{l}\text { Contagion (finished) } \\
\text { [Figure } 7(\mathrm{t})]\end{array}$} & Verbal & $\begin{array}{l}\text { He mentioned the red ring, the crosshairs, the coloured } \\
\text { plumes, which he called smoke, and the date stamps. }\end{array}$ \\
\hline & \multirow[t]{4}{*}{ Physical } & Tested it by moving around. \\
\hline & & $\begin{array}{l}\text { Walked around for a long while trying to avoid her shadow } \\
\text { being projected onto the screen. }\end{array}$ \\
\hline & & Experimented with stepping in and out of the active area. \\
\hline & & $\begin{array}{l}\text { She moved very little, choosing instead to watch the visuals } \\
\text { develop. }\end{array}$ \\
\hline & \multirow{5}{*}{$\begin{array}{l}\text { Emotional } \\
\text { mental }\end{array}$} & Focused on 'reading' the visual cues of the work. \\
\hline & & $\begin{array}{l}\text { Thought the shadow appearing in the work is a metaphor } \\
\text { for participation in political and social life and reflected on } \\
\text { what her unwillingness to see her shadow projected might } \\
\text { say about her. }\end{array}$ \\
\hline & & $\begin{array}{l}\text { She saw references to surveillance, the military, } \\
\text { globalisation, and disease in the work. }\end{array}$ \\
\hline & & $\begin{array}{l}\text { Struck by how complicated and multi-layered the visuals } \\
\text { became. }\end{array}$ \\
\hline & & $\begin{array}{l}\text { She found the installation encouraged her to be reflective } \\
\text { and quiet. }\end{array}$ \\
\hline
\end{tabular}

Further information on each of the types of human-to-artwork responses is given below. 


\subsubsection{Verbal responses}

None of the artworks that were described in the articles used voice as an interface. There were four artworks for which verbal human-to-artwork responses were mentioned, as participants asked questions and provided comments on their (technical) workings (drafting poems and mood swings) or described out loud what they saw (ALAVs and contagion). It appears therefore that the verbal interactions mentioned were limited to figuring out how the artwork functions.

\subsubsection{Physical responses}

Fourteen artworks triggered physical responses. One of the recurring patterns is the correlation between the physical response of the participants and the affordance (Norman, 2002) of the artwork.

That is, in artworks in which physical objects were the main focus, participants' physical responses were based on the affordance of the object: batting or patting a flying blimp ( $A L A V s)$; swinging, squeezing, touching, tickling, stroking, hitting, or braiding orbs hanging from a wire (mood swings); or making waving, circular, pointing, and oscillating movements with a torch (high arctic).

In screen-centred installations, a distinction can be made between screens depicting concrete imagery and screens that show abstract content. When concrete, recognisable content was shown, participants responded according to the affordance of the depicted subject, as with the real objects mentioned above: stomped their feet as if actually crushing the projected grass (Elysian Fields); leaped, jumped, and tried to depress three projected springs at once, while feeling childlike and free to move in the game-like setting of sprung! or waved with varying speeds and high synchronicity in semi-circular movements at the interactive lights on the London Eye (mood conductor).

In contrast, when the screen showed abstract content, participants mostly used whole-body movements to find out what the responses of the artwork would be. In event horizon, people waved their hands and shook their feet, moved back and forth and even danced. Moving around and stepping in and out were recorded in contagion and spaces of two categories, where people also tried out different paces and movements. In cardiomorphologies, which differed from the other works in its specific heartbeat and breathe rate interface, participants also tried to find out what the depicted abstract content meant by physically trying out divers options.

In large, dark open spaces people tend to 'experience the space' as a void. Comments like 'this is not a room' were made in radiomap. Likewise, in Talk2me, participants sat down and engaged, committing to the space. Gestures were deictic, a feature that can be linked to finding out the workings of the piece, just as with the screen-based installations with abstract content.

In smaller, table-top installations, motions tended to be more sensual, as seen in drafting poems and books of sand. In drafting poems, the movements on the table-top projection were larger than life, exaggerated, while in the real, augmented sand of books of sand they were more considered and slower in pace. 


\subsubsection{Cognitive/emotional responses}

Just as with the physical responses, the most commonly noted cognitive response in artworks depicting abstract content was trying to figure out how the interactive artwork functions. This is described as 'understanding the functioning of the artwork' (galassie, Ombra di Stelle and event horizon), testing/mimicking results (drafting poems), exploring the interface as primary experience (radiomap) and searching for the limits of the installation by trying out different outcomes or searching for camera/screen boundaries and placement (cardiomorphologies and contagion). Participants' frustration derived mainly from the failure to understand how their actions impacted on the work beyond their immediate perception (metastasis).

In order to explore the meaning of an interactive artwork or to be immersed in it, it appears that the interface must be fully explored and understood. This was seen in space of two categories where it was noted that those who did not react as strongly to the reflective aspects of the artwork provided technical solutions more readily than those who did, implying that they did not figure out the interface. Morrison elaborates: 'the interaction starts at the moment of understanding'; and participants themselves confirmed this in cardiomorphologies: 'the interaction starts at the moment of understanding, prior [to which] everything is just mucking around'. Reaching the phase where the meaning is explored proved difficult: only $9 \%$ of individuals and $17 \%$ of groups reached it in mood swings. Therefore, Hohl argues when evaluating radiomap: 'a novel and unfamiliar method of navigation may not be recommended for computer mediated experience intended to facilitate reflective and introspective insights'. The interface is therefore the most important piece of an interactive artwork, because if it is lacking, the meaning is not even explored. Hespanhol and Tomitsch phrased this as follows: 'Immediate feedback that is directly mapped to the participant's actions is more important for engagement than a clear narrative'.

Feeling a personal connection and recognition with an aspect of an interactive artwork, like the sound of snow, can result in a more enthusiastic and immersive experience (e.g., Elysian Fields and just a bit of spin).

Closely linked to the feeling of perceiving large, dark open spaces as a void, participants mentioned underestimating the time spent in them (radiomap and space of two categories).

If participants feel shy, self-conscious, incompetent, or insecure, they may decide not to engage (just a bit of spin prototype, metastasis) or might take the role of passive observers, watching the activity and/or listening in on discussions (Talk2me, just a bit of spin redesign).

\subsubsection{Human-human}

All but four of the studies considered here include human-human response data (Table 5), although the available information is in general less extensive than that for human-artwork responses. Again, verbal, physical, and cognitive/emotional responses can be distinguished.

Further information on each of the types of human-artwork responses is given below. 


\subsubsection{Verbal responses}

In the recorded interhuman verbal responses, (brief) discussions about the work occurred spontaneously $(A L A V s)$ and participants gave and received instructions about the way the artwork worked (ALAVs, drafting poems, Untitled, contagion (prototype), space of two categories).

Table 5 Human-human responses

\begin{tabular}{|c|c|c|}
\hline \multirow{2}{*}{$\begin{array}{l}\text { Artwork } \\
\text { Audio-only augmented } \\
\text { reality system for social } \\
\text { interaction [Figure } 7(a)]\end{array}$} & \multicolumn{2}{|r|}{ Human-human response } \\
\hline & Physical & $\begin{array}{l}\text { Decrease in 'dancing with known people' } \\
(t(14)=-2.5, p=0.01)\end{array}$ \\
\hline \multirow[t]{6}{*}{$\begin{array}{l}\text { Galassie [Figure } 7(\mathrm{~b})] \\
\text { Ombra di Stelle } \\
\text { [Figure } 7(\mathrm{c})]\end{array}$} & Physical & $\begin{array}{l}\text { Co-testing and co-playing: Users oriented both to the } \\
\text { artwork and to the people accompanying them. People } \\
\text { in these groups tended to focus together on the same } \\
\text { portion of the installation, and to take turns testing or } \\
\text { playing with the artwork. }\end{array}$ \\
\hline & & $\begin{array}{l}\text { Imitation: Visitors learned how to interact with an } \\
\text { artwork by observing others. }\end{array}$ \\
\hline & $\begin{array}{l}\text { Cognitive/ } \\
\text { emotional }\end{array}$ & $\begin{array}{l}\text { Fifty-seven acknowledged other people's influence: } 31 \\
(44.3 \%, n=70) \text { reported having being influenced by } \\
\text { others, } 10 \text { positively }-3 \text { said it added explicitly to the } \\
\text { positive value of their experience; } 10 \text { negatively - } 4 \\
\text { stated they preferred a private experience. }\end{array}$ \\
\hline & & $\begin{array}{l}\text { Emotions perceived in others ( } 72 \text { answers, } 21 \\
\text { describing more than one feeling) - } 72 \text { positive, } \\
\text { including ludic pleasure (23), interest (23), amazement } \\
\text { (13), transport (2); } 11 \text { negative, including: confusion } \\
\text { (6), indifference (3). }\end{array}$ \\
\hline & & 11 did not know the feelings of others. \\
\hline & Misc. & Three major phases: circumspection, testing, play. \\
\hline \multirow[t]{11}{*}{ ALAV [Figure $7(d)]$} & Verbal & $\begin{array}{l}\text { Conversations were interrupted by brief discussions } \\
\text { about the ALAVs. }\end{array}$ \\
\hline & & $\begin{array}{l}\text { Actively searching for more info (from the artists or } \\
\text { others) on how to feed the ALAV through imitation or } \\
\text { information. }\end{array}$ \\
\hline & & Speculative play: comprehension. \\
\hline & Physical & Batting an ALAV towards somebody else (free-play). \\
\hline & $\begin{array}{l}\text { Cognitive/ } \\
\text { emotional }\end{array}$ & $\begin{array}{l}\text { A sense of camaraderie developed between the } \\
\text { 'batters'. }\end{array}$ \\
\hline & & Smiling and general goodwill. \\
\hline & & Bond formed with fellow feeders. \\
\hline & Misc. & $\begin{array}{l}\text { A sense of camaraderie developed between the } \\
\text { 'batters'. }\end{array}$ \\
\hline & & Smiling and general goodwill. \\
\hline & & Bond formed with fellow feeders. \\
\hline & & Interactive play. \\
\hline
\end{tabular}


Table 5 Human-human responses (continued)

\begin{tabular}{|c|c|c|}
\hline Artwork & & Human-human response \\
\hline \multirow{9}{*}{$\begin{array}{l}\text { Drafting poems } \\
\text { [Figure } 7(\mathrm{e})]\end{array}$} & \multirow[t]{4}{*}{ Verbal } & Discussions about the workings. \\
\hline & & Verbal play. \\
\hline & & Coaching the 'interactor'. \\
\hline & & Situated social play. \\
\hline & Physical & Handing over the pen to the next user. \\
\hline & $\begin{array}{l}\text { Cognitive/ } \\
\text { emotional }\end{array}$ & $\begin{array}{l}\text { An informal, shifting community emerged. Groups of } \\
\text { people tended to linger around. }\end{array}$ \\
\hline & \multirow[t]{3}{*}{ Misc. } & Cooperative play. \\
\hline & & Associative play. \\
\hline & & Interactive play. \\
\hline \multirow{5}{*}{$\begin{array}{l}\text { Books of sand } \\
\text { [Figure } 7(f)]\end{array}$} & \multirow[t]{2}{*}{ Verbal } & Verbal play/dialogue. \\
\hline & & Speculation. \\
\hline & Physical & $\begin{array}{l}\text { Consideration of and moving around the hands of } \\
\text { others occurred naturally. }\end{array}$ \\
\hline & \multirow[t]{2}{*}{ Misc. } & Cooperative play. \\
\hline & & Associative play. \\
\hline \multirow[t]{6}{*}{ Radiomap [Figure 7(g)] } & \multirow[t]{3}{*}{ Verbal } & Collaborating. \\
\hline & & Negotiating. \\
\hline & & Communicating. \\
\hline & \multirow{3}{*}{$\begin{array}{l}\text { Cognitive/ } \\
\text { emotional }\end{array}$} & Being observed. \\
\hline & & Interconnectedness. \\
\hline & & $\begin{array}{l}\text { Collaborating with other participants created a layer of } \\
\text { complexity that distracted attention and prevented } \\
\text { immersion into the actual environment.: 'when I used } \\
\text { it on my own, I had a relationship with the circle, ... } \\
\text { when I used it with you, I had a relationship to you'. }\end{array}$ \\
\hline $\begin{array}{l}\text { Space of two categories } \\
\text { [Figure } 7(\mathrm{~h})]\end{array}$ & \multirow[t]{2}{*}{ Verbal } & $\begin{array}{l}\text { 'Wondered how to wave: somebody told me how to do } \\
\text { that' (while enjoying watching the girl move). }\end{array}$ \\
\hline $\begin{array}{l}\text { Mood swings (session 1) } \\
\text { [Figure 7(i)] }\end{array}$ & & $\mathrm{n} / \mathrm{a}$ \\
\hline $\begin{array}{l}\text { Mood swings (session 2) } \\
\text { [Figure 7(i)] }\end{array}$ & Misc. & $\begin{array}{l}\text { Participants in group condition saw significantly more } \\
\text { colours (mean } 5.4 \text { colours) than participants in } \\
\text { individual condition (mean } 3.8 \text { colours) } \\
(t(18)=-2.638, p=0.009) \text {. }\end{array}$ \\
\hline \multirow[t]{2}{*}{ High arctic [Figure 7(j)] } & \multirow[t]{2}{*}{ Misc. } & $\begin{array}{l}\text { Most people found that the exhibition did not assist } \\
\text { with or generate collaboration between people as an } \\
\text { underlying consequence of their interaction. }\end{array}$ \\
\hline & & $\begin{array}{l}\text { People who interacted with others (generally it appears } \\
\text { they were friends or relatives) learnt from one another } \\
\text { ways of manipulating the projections, and such } \\
\text { collaborations appeared to extend the duration of } \\
\text { interaction. }\end{array}$ \\
\hline
\end{tabular}


Table 5 Human-human responses (continued)

\begin{tabular}{|c|c|c|}
\hline \multirow{2}{*}{$\begin{array}{l}\text { Artwork } \\
\text { Event horizon } \\
\text { [Figure } 7(\mathrm{k})]\end{array}$} & \multicolumn{2}{|r|}{ Human-human response } \\
\hline & Verbal & $\begin{array}{l}\text { The interaction encouraged discussion between } \\
\text { friends. }\end{array}$ \\
\hline Untitled [Figure 7(l)] & Verbal & $\begin{array}{l}\text { Some of them discussed the audible interaction with } \\
\text { friends. }\end{array}$ \\
\hline \multirow[t]{11}{*}{ Talk2me [Figure 7(m)] } & Verbal & $\begin{array}{l}\text { Mode of coresponders: responded back to others and } \\
\text { the robots. }\end{array}$ \\
\hline & & Instances of verbal play. \\
\hline & Physical & Handing over the activity spot to others. \\
\hline & & $\begin{array}{l}\text { Situated social play through the work: participants } \\
\text { interacted with others through the work. }\end{array}$ \\
\hline & & Instances of embodied play. \\
\hline & $\begin{array}{l}\text { Cognitive/ } \\
\text { emotional }\end{array}$ & $\begin{array}{l}\text { Observers: participants passively watched the activity } \\
\text { and/or listened in on the discussions. }\end{array}$ \\
\hline & & Instances of entering into the spirit of play. \\
\hline & & Instances of associative play. \\
\hline & & Instances of cooperative play. \\
\hline & & $\begin{array}{l}\text { Informal understanding that participation in a public } \\
\text { environment is largely a democratic process, with most } \\
\text { participants being polite and sharing accordingly. }\end{array}$ \\
\hline & & $\begin{array}{l}\text { Some, relatively few, instances of competitive } \\
\text { behaviour: trying to dominate activity or stay within a } \\
\text { group of friends. }\end{array}$ \\
\hline \multirow{2}{*}{$\begin{array}{l}\text { Elysian Fields } \\
\text { [Figure } 7(n)]\end{array}$} & \multirow{2}{*}{$\begin{array}{l}\text { Cognitive/ } \\
\text { emotional }\end{array}$} & Competition: 7 \\
\hline & & Camaraderie: 8 \\
\hline \multirow[t]{5}{*}{ Sprung! [Figure 7(o)] } & \multirow[t]{5}{*}{$\begin{array}{l}\text { Cognitive/ } \\
\text { emotional }\end{array}$} & $\begin{array}{l}\text { Most of the people (6/8) who experienced camaraderie } \\
\text { experienced it in pairs: they played sounds together } \\
\text { and caused bubbles to trigger sounds together. }\end{array}$ \\
\hline & & $\begin{array}{l}\text { Felt childlike and free to move in physically pleasing } \\
\text { ways; their partner enjoyed watching them do this. }\end{array}$ \\
\hline & & $\begin{array}{l}\text { Performative character (especially in pairs, where the } \\
\text { partner serves as an audience). }\end{array}$ \\
\hline & & Camaraderie: 11 \\
\hline & & Competition: 7 \\
\hline \multirow{2}{*}{$\begin{array}{l}\text { Just a bit of spin } \\
\text { (prototype) [Figure } 7(p)]\end{array}$} & \multirow{2}{*}{$\begin{array}{l}\text { Cognitive/ } \\
\text { emotional }\end{array}$} & Camaraderie: 6 \\
\hline & & Competition: 8 \\
\hline \multirow{4}{*}{$\begin{array}{l}\text { Just a bit of spin } \\
\text { (redesign) [Figure 7(p)] }\end{array}$} & Verbal & Are you finished? - taking over control. \\
\hline & Physical & Taking turns turning the wheel. \\
\hline & \multirow{2}{*}{$\begin{array}{l}\text { Cognitive/ } \\
\text { emotional }\end{array}$} & Camaraderie: 13 \\
\hline & & Competition: 19 \\
\hline
\end{tabular}


Table 5 Human-human responses (continued)

\begin{tabular}{|c|c|c|}
\hline \multirow{2}{*}{$\begin{array}{l}\text { Artwork } \\
\text { Metastasis [Figure 7(q)] }\end{array}$} & \multicolumn{2}{|r|}{ Human-human response } \\
\hline & $\begin{array}{l}\text { Cognitive/ } \\
\text { emotional }\end{array}$ & $\begin{array}{l}\text { Frustration derived mainly from failure to understand } \\
\text { how their actions impacted anything in the work } \\
\text { beyond their immediate reflection, as if they were } \\
\text { walking in the middle of someone else's experience. }\end{array}$ \\
\hline & & $\begin{array}{l}\text { Previous acquaintance between the participants seemed } \\
\text { to be highly relevant for effective personal interaction } \\
\text { when a casual encounter was forged within an } \\
\text { immersive space. Almost all people who knew each } \\
\text { other prior to the session ( } 3 \text { out of } 4 \text { ) felt inclined to } \\
\text { interact when meeting within the space. Conversely, } \\
\text { the majority of those who did not previously know } \\
\text { each other ( } 3 \text { out of } 4 \text { ) also decided not to engage in } \\
\text { social interaction in this particular scenario. }\end{array}$ \\
\hline & & $\begin{array}{l}\text { Previously established social ties seemed to have been } \\
\text { reinforced by the immersive situation. }\end{array}$ \\
\hline & & $\begin{array}{l}\text { When not alone, participants reported a significant } \\
\text { shift of their focus from their inner emotions to the } \\
\text { other (familiar or unfamiliar) person's actions, how the } \\
\text { space could be negotiated, and how their joint actions } \\
\text { affected the content of the screens. }\end{array}$ \\
\hline $\begin{array}{l}\text { The mood conductor } \\
\text { [Figure } 7(\mathrm{r}) \text { ] }\end{array}$ & & $\mathrm{n} / \mathrm{a}$ \\
\hline $\begin{array}{l}\text { Cardiomorphologies } \\
\text { (prototype) [Figure 7(s)] }\end{array}$ & & $\mathrm{n} / \mathrm{a}$ \\
\hline \multirow{6}{*}{$\begin{array}{l}\text { Contagion (prototype) } \\
\text { [Figure } 7(\mathrm{t})]\end{array}$} & Verbal & Tried to explain to the children that it is interactive. \\
\hline & & $\begin{array}{l}\text { Told him that it was tracking his movement and he } \\
\text { experimented by moving around in the space. }\end{array}$ \\
\hline & Physical & Played tag with a child that came in. \\
\hline & & He and his wife stood back and watched. \\
\hline & & Watched others moving in the space. \\
\hline & $\begin{array}{l}\text { Cognitive/ } \\
\text { emotional }\end{array}$ & $\begin{array}{l}\text { A number of children entered the space during the } \\
\text { interview and she compared their experience with her } \\
\text { own }\end{array}$ \\
\hline $\begin{array}{l}\text { Contagion (finished) } \\
\text { [Figure } 7(\mathrm{t})]\end{array}$ & & $\mathrm{n} / \mathrm{a}$ \\
\hline
\end{tabular}

Participants verbally coached the person who was interacting with the artwork (drafting poems) or started to (verbally) work together (books of sand). People also verbally negotiated turns, for example 'are you done?' (books of sand, just a bit of spin). 


\subsubsection{Physical responses}

If human-to-human physical responses were noted regarding an artwork, most of them involved participants interacting together with the artwork or with each other through the artwork. In three works with abstract content, it was observed that participants learned how to interact with the artwork by observing and imitating others or by trying it out together (galassie, Ombra di Stelle, and contagion).

Participation in a public environment was generally a democratic process. Participants were polite and shared freely in Talk2me. They coordinated their behaviour with that of their peers [called 'cooperative play' by Morrison; ALAV, drafting poems, books of sand, Talk2me (Morrison et al., 2011a)]. In the sandbox of books of sand, the researchers observed "[c]onsideration of and moving around the hands of others occurring naturally”. Overall, participants naturally took turns testing and playing with the artwork: they handed over the pen (drafting poems), the activity spot (Talk2me), the wheel (just a bit of spin), or their turn (galassie, Ombra di Stelle) to the next user.

\subsubsection{Cognitive/emotional responses}

In metastasis, participants noted a shift in their focus from their inner emotions to the other person's actions, negotiating the space, and managing joint actions. In galassie and Ombra di Stelle, participants were evenly divided between perceiving others' influence as positive or negative. In mood swings, however, participants in the group condition saw significantly more colours (mean 5.4) than participants in the individual condition (mean 3.8). Similarly, in high arctic, people who interacted with others learned from one another, and their collaboration led to extended time spent interacting with the artwork.

It is important to note that in high arctic all viewers appeared to be friends or relatives, a relation also found in metastasis: "previous acquaintance between the participants seems to be highly relevant for effective personal interaction when a casual encounter [was] forged within an immersive space. Almost all people who knew each other prior to the session (3 out of 4) felt inclined to interact when meeting within the space. Conversely, the majority of those who did not previously know each other (also 3 out of 4) decided not to engage in social interaction in this particular scenario. Previously established social ties seem to have been reinforced by the immersive situation" (Hespanhol and Tomitsch, 2014).

When people did not know each other, the affordance of the installation determines how they interact. In the playful $A L A V$ installation, a sense of camaraderie developed as people batted the $A L A V s$ towards each other and those who 'fed' the $A L A V s$ bonded as well - this in contrast with the informal shifting community of groups of people that lingered around the projections of poetry in the sand of the table-top sandbox in books of sand.

\section{Discussion}

The main aim of this article was to undertake a systematic review of studies describing responses of participants to physical, open-ended interactive digital artworks. Both human-to-artwork and human-to-human responses were seen regarding the 22 artworks that were reviewed, but the former were more frequently reported than the latter. Both 
types of responses were further categorised into physical, verbal, and cognitive/emotional responses.

The artworks varied from small table-top installations to large, dark open spaces, and had a range of interactive components and features, from a heart rate interface to complete body movements.

Based on the results of this review, there does not seem to be a straightforward relationship between the type of artwork (i.e., its features) and the kind of response (e.g., human-to-artwork or human-to-human, or the subtype of response, such as physical response). However, two factors were identified that seemed to influence the participants' responses: the content (real or abstract) of the artwork, and the presence of others.

The first thing participants did when they encountered an interactive installation for the first time was to figure out how the interface worked. Participants responded according to the affordance of the real or depicted object, and when they could relate to the things they saw/experienced, they connected more easily with the installation. When abstract content was shown, most participants first tried to figure out how the artwork functioned by trying out different options, alone or together. Thus, when creating an interactive artwork that wants to convey a message or aims to be an immersive experience, it would appear to be important to have an interface with a learning curve that is not too steep. When participants become frustrated figuring out the way the interface works, or when it becomes the most important part of the experience, a deeper level of understanding is never reached.

It should be pointed out that this is a fairly new phenomenon, and many of the participants whose data is presented here did not have prior experience with interactive art. Maybe understanding the interfaces of interactive artworks is an acquired skill? In space of two categories, it seems that being a frequent gallery visitor can also help one to more quickly 'read' the intentions of an artwork and to reflect on its meaning. As no returning visitors were identified in the present data, questions remain regarding how participants react when they encounter the same installation for a second, third, or fiftieth time. Will 'exploring the interface' be skipped in these cases, or is it a vital part of the experience that will persist if allowed, and should the interface evolve to remain interesting?

The effect of the presence of other people while interacting with an artwork is not necessarily clear or consistent, but it does seem that other visitors can influence one's experience. For instance, when people know each other, previously established social ties can be reinforced. Moreover, while the presence of strangers seems to be no problem in play-like environments, in more immersive works others are 'ignored' in a very natural way, but it can also be perceived as "another layer of complexity that distracts attention and prevents immersion into the actual environment” [Hohl, (2009), p.11], or by shifting their own focus from their inner emotions to the other person's actions. The 'social tolerance' of a given work might be proportionally linked to the distribution of focal points in the work. Interacting with an artwork in front of others may create a threshold to participation, leading instead to passive observation. 


\section{Methodological considerations}

In order to be included in this review, articles needed to evaluate user responses to a physical, open-ended digital artwork. Because of the small number of articles discussing user responses to these types of artwork, no additional quality criteria were set.

We identified 13 studies that described responses of participants to 22 physical, open-ended interactive digital artworks. This is a very small number compared to the huge number of multimedia festivals, exhibitions, and commercial interactive installations that are built and exhibited every year.

Because there is no standard database for studies into interactive art (on the model of e.g., PubMed for medical research), we selected five relevant databases based on the number of search results for the term 'interactive art'. A number of terms are in current use in the literature to refer to interactive art installations and user responses (see the introduction). The first author compiled a list of terms [Figure 5(a)] found in the literature of the initial searches, continuing the search until no new terms were found. It is, however, possible that terms or combinations were missed. In combining the terms, an extensive query emerged [Figure 5(b)], which could not be managed by all selected databases. Therefore, a compact query was created and used alongside the full query [Figure 5(c)], which was applied in chunks if necessary. This may have led to results being missed.

\section{Conclusions}

The results indicate that interactive artworks can evoke a variety of verbal, physical, and cognitive/emotional responses within and between visitors, making these artworks powerful instruments. Interactive art has the potential to be used as an intentional immersive technology in domains where people have a hard time understanding, experiencing, and/or communicating with the world and people around them due to a permanent or temporary physical and/or cognitive condition. For example, when an interactive work of art is created that is tailored to residents of nursing homes, such as those diagnosed with Alzheimer's disease, they could experience the benefits of communicating with the people and the world around them through the artwork and/or of enjoying an aesthetic experience.

Most of the interactive art installations created today are not formally studied, because there are more people making interactive art than studying it. Some of these artworks intend to facilitate specific responses. Creating interactive artworks that can challenge new audiences and/or evoke specific responses requires more knowledge about the complex relationships and dynamics of people interacting with an interactive artwork and people interacting with each other through/within such an artwork. At present, studies of interactive artworks use different frameworks to assess the participants' responses. This makes it hard to objectively compare a large number of interactive artworks. Explorative studies should be carried out to assess which domains and target audiences can benefit from the immersive experience and the resulting effects of interactive art. 


\section{References}

Bialoskorski, L.S.S., Westerink, J.H.D.M. and van den Broek, E.L. (2010) 'Experiencing affective interactive art', Int. J. Arts and Technology, Vol. 3, No. 4, pp.341-356.

Bilda, Z., Costello, B. and Amitani, S. (2006) 'Collaborative analysis framework for evaluating interactive art experience’, CoDesign, Vol. 2, No. 4, pp.225-238.

Burke, L., Kleinman, S. and Cheung, T. (2012) Branching Out, New York.

Capybara Games and Superbrothers (2011) Swords and Sworcery, Toronto.

Costello, B., Muller, L., Amitani, S. and Edmonds, E. (2005) 'Understanding the experience of interactive art: iamascope in beta_space', Proceedings of the Second Australasian Conference on Interactive Entertainment, Creativity \& Cognition Studios Press, Sydney, Australia, pp.49-56.

Deray, K. and Simoff, S.J. (2012) 'Framing interaction through engagement in interactive open ended environments', 16th International Conference on Information Visualisation, IEEE Computer Society, Montpellier, France, pp.534-539.

Dourish, P. (2004) Where the Action Is: The Foundations of Embodied Interaction, MIT Press, Cambridge.

Edmonds, E. and Candy, L. (2011) Interacting: Art, Research and the Creative Practitioner, Libri Publishing, Faringdon.

Fourneau, A. (2013) Water Light Graffiti, Paris.

Griffiths, J.L. (2009) Drawing Machine \#1, Melbourne.

Gurion, T. and Jacoby, N. (2013) 'Audio-only augmented reality system for social interaction', HCI International 2013 - Posters’ Extended Abstracts, Springer, Berlin/Heidelberg.

Her, J.J. and Hamlyn, J. (2010) 'meaningful engagement: computer-based interactive media art in public space', Arts and Technology: First International Conference, Springer, Berlin/ Heidelberg, pp.17-24.

Hespanhol, L. and Tomitsch, M. (2014) 'Understanding the effects of contextual constraints on performative behaviour in interactive media installations', Personal and Ubiquitous Computing, Vol. 18, No. 7, pp.1651-1665.

Hohl, M. (2009) 'Designing the art experience: using grounded theory to develop a model of participants' perception of an immersive telematic artwork', Digital Creativity, Vol. 20, No. 3, pp.187-196.

I/O Design (2013) Weather Worlds, Norfolk.

Itten, J. (1973) The Art of Color: The Subjective Experience and Objective Rationale of Color, New York, John Wiley \& Sons, Inc.

Jacucci, G., Spagnolli, A., Chalambalakis, A., Morrison, A., Liikkanen, L., Roveda, S. and Bertoncini, M. (2009) 'Bodily explorations in space: social experience of a multimodal art installation', Human-Computer Interaction - INTERACT, Springer, Berlin/Heidelberg, pp.62-75.

Klink, S. and Urban Alliance (2009) Moodwall, Amsterdam.

Lab212 (2012) Starfield, Montreuil.

Lee, J-H., Park, J-Y. and Nam, T-J. (2007) 'Emotional interaction through physical movement', in Jacko, J. (Eds.): Human-Computer Interaction (HCI) Intelligent Multimodal Interaction Environments, Springer, Berlin/Heidelberg, pp.401-410.

Moher, D., Liberati, A., Tetzlaff, J., Altman, D.G. and The PRISMA Group (2009) 'Preferred reporting items for systematic reviews and meta-analyses: the PRISMA statement', PLoS Med, Vol. 6, No. 6, p.3, e1000097, doi: 10.1371/journal.pmed1000097.

Morgan, E. and Gunes, H. (2013) 'Human nonverbal behaviour understanding in the wild for new media art', in Salah, A.A., Hung, H., Aran, O. and Gunes, H. (Eds.): Human Behavior Understanding, Springer, Barcelona, pp.27-39. 
Morrison, A.J., Mitchell, P. and Viller, S. (2008) 'Evoking gesture in interactive art', HCC '08: Proceedings of the 3rd ACM International Workshop on Human Centered Computing, ACM, New York, USA, pp.11-18.

Morrison, A.J., Viller, S. and Mitchell, P. (2011a) 'Building sensitising terms to understand freeplay in open-ended interactive art environments', Proceedings of the SIGCHI Conference on Human Factors in Computing Systems, ACM, Vancouver, Canada, pp.2335-2344.

Morrison, A.J., Viller, S. and Mitchell, P. (2011b) 'Open-ended art environments motivate participation', Proceedings of the 8th International Conference on Advances in Computer Entertainment Technology, ACM, Lisbon, Portugal, pp.1-8.

Muller, E. (2008) The Experience of Interactive Art: A Curatorial Study, PhD thesis, University of Technology, Sydney, Australia.

Nardelli, E. (2012) 'A classification framework for interactive digital artworks', in Alvarez, F. and Costa, C. (Eds.): User Centric Media, Springer, Berlin/Heidelberg, pp.91-100.

Norman, D.A. (2002) The Design of Everyday Things, Basic Books, New York.

Robinson, J. (2007) Deeper Than Reason: Emotion and Its Role in Literature, Music, and Art, Clarendon Press, Oxford.

Roosegaarde, D. (2011) Lunar, Breda.

Schraffenberger, H. and Heide, E. (2012) 'Interaction models for audience-artwork interaction: current state and future directions', in Brooks, A. (Eds.): Arts and Technology, Springer, Berlin/Heidelberg, pp.127-135.

SensoriumHealth (2014) BrightHearts, Sydney.

Völker, N. (2010) One Hundred and Eight, Berlin. 